\title{
Effects of park walks and relaxation exercises during lunch breaks on recovery
}

\section{from job stress: Two randomized controlled trials}

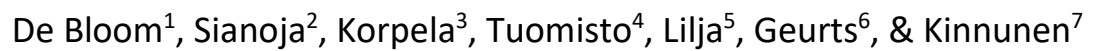

Please cite as: De Bloom, J., Sianoja, M., Korpela, K., Tuomisto, M., Lilja, A., Geurts, S., \& Kinnunen, U. (2017). Effects of park walks and relaxation exercises during lunch breaks on recovery from job stress: Two randomized controlled trials. Journal of Environmental Psychology, 51, 14-30. doi: http://doi.org/10.1016/j.jenvp.2017.03.006

Acknowledgements:

This study was supported by the Academy of Finland (grant no. 257682) as part of a larger research project entitled: "Recovery from job stress: Integrating perspectives of work and environmental psychology".

Additional information:

The research plan for this study was approved by the Ethics Committee of the Tampere Region (Statement 10/2014), the trial was registered (NCT02124837) and the study protocol published (De Bloom, Kinnunen, \& Korpela, 2014).

\footnotetext{
${ }^{1}$ Dr. Jessica de Bloom, Institute of Advanced Social Research, 33014 University of Tampere, Tampere, Finland; jessica.de.bloom@uta.fi, tel.: +358 503186070 (corresponding author)

${ }^{2}$ Marjaana Sianoja, School of Social Sciences and Humanities (Psychology), 33014 University of Tampere, Tampere, Finland; marjaana.sianoja@uta.fi

${ }^{3}$ Professor Kalevi Korpela, School of Social Sciences and Humanities (Psychology), 33014 University of Tampere, Tampere, Finland; kalevi.korpela@uta.fi

${ }^{4}$ Professor Martti Tuomisto, School of Social Sciences and Humanities (Psychology), 33014 University of Tampere, Tampere, Finland; martti.tuomisto@uta.fi

${ }^{5}$ Ansa Lilja, Centre for Applied Statistics and Data Analytics, University of Tampere, Tampere, Finland; ansa.lilja@staff.uta.fi

${ }^{6}$ Professor Sabine Geurts, Behavioural Science Institute, Radboud University, Nijmegen, Netherlands; s.geurts@psych.ru.nl

${ }^{7}$ Professor Ulla Kinnunen, School of Social Sciences and Humanities (Psychology), 33014 University of Tampere, Tampere, Finland; ulla.kinnunen@uta.fi
} 


\title{
Effects of park walks and relaxation exercises during lunch breaks on recovery from job stress: Two randomized controlled trials
}

\begin{abstract}
Lunch breaks constitute the longest within-workday rest period, but it is unclear how they affect recovery from job stress. We conducted two randomized controlled trials with 153 Finnish knowledge workers who engaged for 15 minutes daily in prescribed lunch break activities for ten consecutive working days. Participants were randomly assigned to a: 1$)$ park walking group ( $N=$ $51), 2)$ relaxation exercises group $(N=46)$ and 3$)$ control group $(N=56)$. The study was divided into two parts scheduled in spring $(N=83)$ and fall $(N=70)$. Recovery experiences (detachment, relaxation, enjoyment) and recovery outcomes (restoration, fatigue, job satisfaction) were assessed with SMS and paper-and-pencil questionnaires several times per day before, during and after the intervention period. A manipulation check revealed that both intervention groups reported less tension after lunch breaks during the intervention than before. In spring, the interventions did hardly affect recovery experiences and outcomes. In fall, restoration increased and fatigue decreased markedly immediately after lunch breaks and in the afternoon in both intervention groups ( $d=0.22-0.58)$ and most consistent positive effects across the day were reported by the park walking group. Park walks and relaxation exercises during lunch breaks can enhance knowledge workers' recovery from work, but effects seem weak, short-lived and dependent on the season.
\end{abstract}

\section{Key words}

detachment, fatigue, job satisfaction, nature, recovery, restoration 


\section{Introduction}

Employees spend about half of their waking time at work and most workers are legally entitled to a daily lunch break. Lunch breaks therefore constitute an important opportunity to recover on a regular basis from the present day's extremely demanding work. Recovery enables employees to stop depleting their resources and replenish their psychological and physical resources, and preserve full working capacities and occupational health (e.g., Sonnentag \& Zijlstra, 2006). Despite the alleged importance of lunch breaks, there is a lack of evidence on the effects of lunch breaks on employee well-being and in particular on the role of break-time activities and experiences. Even rarer are intervention studies, which could help to establish causal links between break activities, recovery experiences, and well-being. Besides, the physical break environment and its impact on recovery from work has so far attracted little attention (Korpela, De Bloom, \& Kinnunen, 2015; Korpela \& Kinnunen, 2011).

In occupational health psychology, recovery from work has been conceptualized as a key mechanism in the relationship between acute job stress and long-term well-being (Geurts \& Sonnentag, 2006). According to the effort recovery model (Meijman \& Mulder, 1998) and the conservation of resources theory (Hobfoll \& Shirom, 2001), two mechanisms assist recovery: reduction or removal of demands, and creation of new resources.

Expending psychological and physical effort at work drains employees ` psycho-physiological resources and sets in motion a health impairment process (Schaufeli, Bakker, \& Van Rhenen, 2009). Recovery constitutes a reversal of this process and, accordingly, can only occur when job demands and stressors are removed, that is, when work ceases (Meijman \& Mulder, 1998). This enables employees to replenish lost resources, resulting in lower levels of ill-being (Tay \& Diener, 2011). An employee's subjective experiences associated with this demand reduction process have been termed recovery experiences (Sonnentag \& Fritz, 2007). Numerous studies have 
demonstrated that, of the recovery experiences, in particular psychological detachment (i.e., psychological disengagement from work-related thoughts; Sonnentag \& Fritz, 2007) and mental relaxation during off-job time (i.e., few or no demands and low psycho-physiological activation, little physical or intellectual effort, positive mood; Stone, Kennedy-Moore, \& Neale, 1995; Tinsley \& Eldredge, 1995) reduce strain and help working people to replenish lost resources (Brosschot, Gerin, \& Thayer, 2006; Etzion, Eden, \& Lapidot, 1998; Sonnentag \& Fritz, 2007, 2015; Ursin \& Eriksen, 2004). Relaxation exercises which assist people to calm down constitute one of the most frequently studied and applied stress reduction methods (Richardson \& Rothstein, 2008; van Dixhoorn \& White, 2005).

In environmental psychology, this process of recovery has been referred to as "perceived restorativeness" or "restoration" (Korpela et al., 2015). Restoration refers to the psychophysiological processes of recovering resources that have become diminished in meeting the demands of everyday life (Hartig, 2004) and is considered the opposite of elevated physiological arousal and negative emotions (Korpela et al., 2015). Psychological detachment is also considered a crucial element within this framework, referred to as "being away" (Hartig, Korpela, Evans, \& Gärling, 1997).

Whilst reduction of demands constitutes the first recovery mechanism, the second mechanism relates to engagement in pleasant, self-selected activities. Engaging in joyful activities is intrinsically motivating, helps employees to fulfill higher order needs and build new resources (Sonnentag, 2001). Recovery may thus occur if people engage in activities which they perceive enjoyable. Numerous studies have shown that leisure activities which people enjoy doing (and which may entail investment of effort) are indeed associated with increases in positive affect and higher levels of well-being (Pressman et al., 2009; Ryan, Bernstein, \& Brown, 2010; Tay \& Diener, 2011; Waterman, 2005; Winwood, Bakker, \& Winefield, 2007). Physical exercise is an example of 
an effortful activity that is often highly enjoyed and which can engender long-lasting metabolic changes in the body which positively affect psychological health (Penedo \& Dahn, 2005).

Although the physical environment in which leisure activities take place may greatly affect a person's ability to psychologically detach, relax, and experience joy, it has been largely neglected in recovery research. By contrast, in environmental psychology, the setting, and in particular natural surroundings, are considered pivotal for restoration processes (Hartig, Mitchell, de Vries, \& Frumkin, 2014). For instance, several cross-sectional, longitudinal, and experimental studies have demonstrated that even short exposure to the natural environment improves physical and mental health, and attention-demanding cognitive performance (e.g., Berman, Jonides, \& Kaplan, 2008; Chang, Hammitt, Chen, Machnik, \& Su, 2008; Kaplan \& Berman, 2010). However, the evidence of causal relationships between exposure to natural environments and work-related outcomes in working samples is limited. There is also very little known about how interventions during lunch breaks could utilize leisure activities and physical environments, in particular evidence of the efficiency of interventions in organizational settings is scarce.

In this study, we combine the theoretical frameworks and approaches from work psychology and environmental psychology to explore and evaluate the effects of two different lunch break interventions on employees' recovery from job stress: park walks and relaxation exercises. We conceptualized recovery from work as recovery experiences (detachment, relaxation, enjoyment) and recovery outcomes in terms of well-being (restoration, fatigue, job satisfaction).

\subsection{Park walks}

Research in environmental psychology recognizes the importance of natural environments for people's well-being. According to Kaplan's attention restoration theory (1995), natural environments more than urban settings promote psychological distance from one's usual context, effortless attention, immersion in a coherent physical or conceptual environment, and are often 
compatible with personal purposes. It has been shown that even passively viewing natural rather than urban environments is associated with an increase in positive emotions, a decrease in negative emotions, and improved cognitive performance (Bowler, Buyung-Ali, Knight, \& Pullin, 2010; Hartig, Mang, \& Evans, 1991; Pasanen, Tyrväinen, \& Korpela, 2014). Watching or walking in natural landscapes can increase positive emotions and reduce negative affect (Tsunetsugu et al., 2013), increase vitality (Ryan et al., 2010) and alleviate attentional and physiological fatigue (Hartig, Evans, Jamner, Davis, \& Gärling, 2003; Ulrich et al., 1991).

Brown, Barton, Pretty and Gladwell (2014) found that in a period spanning eight weeks selfreported mental health improved more in those office workers who went for a walk in natural surroundings than in those who walked in an urban environment during their lunch break. A study with adult, mainly female participants showed a greater increase in restorative experiences (e.g., relaxation, forgetting worries), vitality, and positive affect after a 30-minute post-workday walk in an urban park or woodland than in a city center (Tyrväinen et al., 2014). In two other studies with student samples, subjects either took a long walk in a park or in an urban area. The subjects on the park walk achieved a greater improvement in attentional functioning, cardiovascular reactivity and sympathetic arousal (Hartig et al., 2003; Park, Tsunetsugu, Kasetani, Kagawa, \& Miyazaki, 2010). Moreover, nature experiences seem to prepare people to stand future stress and improve consecutive performance (Lee, Williams, Sargent, Williams, \& Johnson, 2015; Parsons, Tassinary, Ulrich, Hebl, \& Grossman-Alexander, 1998).

\subsection{Relaxation exercises}

Relaxation techniques are designed to reduce adverse stress reactions by generating a bodily state that is the physiological opposite of stress. Different strategies can be used to achieve this state, the most common being deep-breathing, and conscious release of muscle tension referred to as progressive muscle relaxation (McCallie, Blum, \& Hood, 2006). Oxygen uptake, and carbon dioxide 
and muscle tension release bring about physiological changes which are incompatible with stress (e.g., lowered blood pressure, heart rate and stress hormone production) and, consequently, mental stress decreases (Esch, Fricchione, \& Stefano, 2003). In addition, some relaxation exercises include mindfulness components. When practicing mindfulness, people are trained to be aware of their current experience and environment and to observe their train of thought without judgement or becoming involved in or identified with the content, referred to respectively as awareness and acceptance (Brown \& Ryan, 2003). Mindfulness interventions have been shown to promote recovery from work stress and improve mental and physical health (Grossman, Niemann, Schmidt, \& Walach, 2004; Hülsheger, Alberts, Feinholdt, \& Lang, 2013; Marzuq \& Drach-Zahavy, 2012).

As far as we know, relaxation exercises during lunch breaks as a strategy to promote recovery from work have been examined only once. In this randomized controlled trial, covering an intervention period of six months, seven call-center agents engaged in 20-minute progressive muscle relaxation during every lunch break while the matched control group engaged in small talk. The researchers reported lower levels of cortisol (Krajewski, Sauerland, \& Wieland, 2011), selfreported strain (Krajewski, Wieland, \& Sauerland, 2010) and sleepiness (Schnieder et al., 2013) in the experimental group than in the control group immediately after the lunch break and also at the end of the afternoon. Richardson and Rothstein (2008) showed in their meta-analysis that occupational stress management interventions utilizing relaxation techniques (e.g., progressive muscle relaxation, meditation, and deep breathing) are effective in reducing strain, and in improving mental health and productivity. 


\subsection{Hypotheses}

We assume that employees who engage in park walking or relaxation exercises during their lunch break will report more beneficial recovery experiences (i.e., relaxation, psychological detachment from work, enjoyment of the lunch break) and higher levels of well-being (i.e., restoration, fatigue, and job satisfaction) than their own baseline levels (within-subject comparison) and also than those persons in the control group (between-subject comparison). Because this study concerned recovery from job stress during lunch breaks, we focused on facets of well-being which are sensitive to changes in energy levels and may fluctuate across working days: restoration, fatigue, and job satisfaction. Restoration is defined as feeling refreshed, attentionally recovered, experiencing positive emotions and low levels of stress and arousal (Korpela et al., 2015). Fatigue refers to a state of physical and mental exhaustion and an aversion to engage in activities that demand high levels of effort (Hockey, 2013). Job satisfaction is defined as a "pleasurable or positive emotional state, resulting from the appraisal of one's job experiences" (Locke, 1976, p. 1300).

We hypothesize that employees engaging in park walking or relaxation during lunch breaks will report more beneficial lunchtime recovery experiences (i.e., higher levels of detachment, relaxation, and enjoyment of lunch breaks) during the intervention period than before ( $\mathrm{H} 1.1)$ and more than employees in the control group continuing their normal break routines (H1.2). Employees engaging in park walking or relaxation during lunch breaks will also report higher levels of well-being (i.e., higher levels of restoration, job satisfaction and lower levels of fatigue) during the intervention period than before $(\mathrm{H} 2.1)$ and more than employees continuing their normal break routines ( $\mathrm{H} 2.2)$. The beneficial effects of lunchtime park walking or relaxation on recovery outcomes may persist after the end of the two-week intervention period. We hypothesize that 
employees engaging in park walking or relaxation during lunch breaks will experience higher levels of well-being after the two-week intervention period than before $(\mathrm{H} 3)$.

On a daily level, we anticipate that the effects will be weaker the more time elapses between the park walking/relaxation exercise and the measurement. Thus, we hypothesize that the potential effects on fatigue and restoration will be stronger after the lunch break than in the afternoon and in the evening $(\mathrm{H} 4)$. This hypothesis matches findings from research showing stronger relationships between stressors and subjective well-being when measures are taken in close proximity (Nixon, Mazzola, Bauer, Krueger, \& Spector, 2011).

This study is the first to simultaneously investigate the effects of park walking and relaxation exercises. We can therefore also compare the impact of these lunch break activities on recovery from work. We speculate that the geographical distance to work, the change in scenery and varied bodily experiences (such as hearing birdsong, smelling the flowers and feeling the sun or the wind on one's skin; see Ratcliffe, Gatersleben, \& Sowden, 2013), and changes in lunchtime routines during park walks may be enjoyed by employees and help them in achieving and keeping mental distance from work (Dart, 2006). In addition to exposure to nature, park walks also involve gentle physical exercise which generally improves well-being and physical health, and speeds up recovery from work (e.g., Feuerhahn, Sonnentag, \& Woll, 2013; Peters, den Dulk, \& van der Lippe, 2009; Reed \& Ones, 2006; von Thiele Schwarz \& Hasson, 2012). Summing up, it is not clear which lunch break activity may be more beneficial, because relaxation exercises are also an evidence-based effective method to reduce tension and unwind from stress (Esch et al., 2003; Richardson \& Rothstein, 2008).

Our study contributes to the literature in three ways: firstly, we focus on the impact of lunch break activities as well as settings on recovery experiences and outcomes, which are surprisingly little researched areas. Secondly, we conducted two randomized controlled trials (RCT's) in an 
organizational context which is still rare but much needed to establish causal links between break behaviors, recovery experiences, and outcomes. Thirdly, in combining theories and approaches from work psychology and environmental psychology, and shedding light on recovery from these slightly different angles, we will advance the integration of these different perspectives on recovery.

\section{Methods}

\subsection{Procedure}

The research plan for the RCT's has been approved by the Ethical Committee of the Tampere Region, Finland. Data collection was divided into two phases to optimize our scarce material and personnel resources. The first RCT took place in spring (starting in week 18) and the second identical RCT in fall 2014 (starting in week 35). Thus, the second RCT in fall was a replication of the RCT in spring. Each RCT lasted five working weeks, two of which were the intervention period. During the intervention weeks participants were instructed to engage for 15 minutes during their lunch break on working days (altogether 10 days) in one of the activities they were randomly assigned to, namely park walking, relaxation exercises, or usual break activities (control group).

Two weeks before the intervention, the participants completed an online questionnaire eliciting demographics (e.g., age, marital status, education), basic work characteristics (e.g., weekly working hours), break habits during the working day (frequency, duration and timing of breaks, usual activities during breaks), and occupational well-being (e.g., job exhaustion).

In the five-week RCT, measurements were taken on eight days three times per day (see Figure 1, first column): on two days before (T1), on four days during (T2) and on two days after (T3) the intervention (Figure 1). On the measurement days (Tuesdays \& Thursdays), recovery experiences and outcomes were assessed with the help of SMS (mobile text messages) 
questionnaires and paper-and-pencil questionnaires. SMS questionnaires were sent to the participants' cell phones three times per day: after lunch (around 12 midday), at the end of the afternoon (i.e., 30-60 minutes before the end of the working day, around 15:15), and in the evening before bedtime (9 PM). Participants had a three-hour period to reply to the messages. At the end of each measurement day, participants also answered questions about their working day presented to them in a paper-and-pencil booklet.

Concerning the measurements, we aimed to strike an optimal balance between the maximum of desired information and a minimal burden of the participants (Fisher, Matthews, \& Gibbons, 2016). This entailed that we measured variables which are more susceptible to momentary changes during the working day (i.e., fatigue) more frequently than variables which we assumed to be more stable across time (i.e., job satisfaction) (e.g., Zacher, Brailsford, \& Parker, 2014).

We took several steps to secure commitment and reduce non-response among the participants as suggested by Newman (2009). For example, a small pilot study was run to make sure the questionnaires were short enough, easily understood, and that the procedure was manageable. Moreover, each participant received a paper calendar, showing all measurement days and the intervention period. An SMS reminder in the evening preceded each measurement day. We also provided verbal and written instructions on the procedure in group sessions at the workplaces, promised individual feedback and emphasized that adherence to the research protocol was essential for the success of this study. After data collection (in November 2014) all participants received individual feedback on their well-being compared to the entire group of participants. We also raffled three lottery prizes (travel vouchers worth $400 €$ in total) and the participants were invited to attend a lecture about the benefits of nature and a training in applied relaxation. 


\subsection{Participants}

We recruited workers with knowledge-intensive and emotionally demanding jobs as it is probable that job stress and recovery problems concern such workers (Allvin, Aronsson, Hagström, Johansson, \& Lundberg, 2011; Hülsheger \& Schewe, 2011). The participants were recruited with the help of a Finnish company supplying occupational health care services. Of the 15 companies contacted, 11 agreed to participate. Workers were contacted by email including a link to a short online registration questionnaire, which also stipulated the following exclusion criteria: a) shift work or extremely irregular working hours and b) serious illness or allergies rendering walking outdoors impossible. We checked that all eleven companies had a park nearby (within five minutes' walking distance). Of the approximately 2,226 people approached, 279 replied and met the criteria, resulting in a response rate of 12.5 percent.

We needed at least six participants from each company to be included in the study, because we organized time intensive group training sessions. This precondition reduced the number of potential participants from 279 to 225 and the number of participating companies to seven. Of the initial sample, 48 people dropped out before the study started and five during the study (e.g., due to sickness, travel plans during intervention weeks, change of employer). After data collection 19 people had to be excluded from the data set because either they did not engage in park walking/relaxation (13 people) or their data were largely missing (6 people). The final sample of 153 people represented $56 \%$ of the initial sample.

As dropout rates at each step were very similar in the spring and fall data collection, the results of attrition analysis was conducted in the combined data set. Thus, in analyzing sample attrition, we compared the final sample $(N=153)$ with those who dropped out immediately before or during the intervention or who were excluded due to non-adherence. The final sample did not differ from the dropouts in terms of intervention group or background characteristics (i.e., gender, 
age, education, occupational status, type of job contract, working hours). However, participants in the final sample experienced less job exhaustion than did dropouts $(M=2.03$ versus 2.57 on a scale from 0 - $6 ; p<.05)$.

The units of the final seven participating companies were assigned to the first or the second phase of the study (spring or fall) and within each company participants were randomized into one of three groups: "Park walk", "Relaxation" and "Control". This was done to avoid contamination (i.e., workers in the fall RCT might have been influenced by co-workers' behavior participating in spring) and intermingling the effects of working conditions at certain companies with "true" intervention effects.

The final sample of the RCT conducted in spring included 83 people from six different organizations. In the fall RTC 70 people from three different companies participated (from two companies, some units took part in the spring and some in the fall). A description of the background variables of the participants for both RCTs is shown in Table I. Differences (except for the company distribution) between the spring and fall RCT samples were related to age and exhaustion: Those participating in spring were older and reported higher levels of exhaustion before the intervention than those participating in fall $(p<.05)$. As expected, due to randomization no differences were found between the three groups (i.e., park walking, relaxation and control group) in background variables (i.e., age, gender, education), basic work characteristics (i.e., type of contract, tenure, weekly working hours, lunch habits), baseline recovery experiences and outcomes (i.e., detachment, relaxation, enjoyment, restoration, fatigue, job satisfaction). 


\subsection{Experimental manipulations}

In the month before the study started, participants were invited to attend a two-hour training session at the company location. The trainers were work- and organizational psychologists (or students at an advanced stage of their studies) who had been trained by the researchers and experts in applied relaxation (psychotherapists) and park walks (environmental psychologists). The procedure was explained in detail and the participants had an opportunity to ask questions. The participants were also given detailed written and verbal instructions for each type of measurement and signed an informed consent form.

\subsubsection{Park walks}

After the common training session, the participants assigned to the park walking group took a guided walk on a predetermined route in the nearest park at a slow, low-intensity pace. They were asked to pay attention to their surroundings and to avoid discussion during this 15-minute walk. The trainers walked the route together with the group during the training and participants were given maps showing the route. In the intervention weeks they could walk either alone or in a group, but were encouraged not to talk to each other. Before and after the park walk participants reported their level of tension on paper.

\subsubsection{Relaxation exercises}

We used two procedures in the relaxation training: 1) a release-only version of progressive muscle relaxation (Öst, 1987) and 2) a deep breathing and acceptance exercise developed by Tuomisto (2007). These methods were targeted at the most important elements in relaxation: muscle relaxation, deep and slow breathing, and acceptance of the here-and-now (Grossman et al., 2004; Hayes-Skelton, Usmani, Lee, Roemer, \& Orsillo, 2012; McCallie et al., 2006). The release-only version of progressive relaxation targets primarily muscle relaxation and the deep breathing exploits the potential of the vagal (i.e., parasympathetic) influence on the autonomic nervous 
system. This method was taught for one hour. The participants were advised that each relaxation session during the intervention period should last 15 minutes and they were given written relaxation instructions, too. Before and after each relaxation exercise, participants reported their level of tension on paper.

\subsection{Measures}

Data collection was time consuming and demanding for the participants, involving over 30 different measurements per person. To reduce the burden on the participants and to prevent dropout, we measured most constructs with single-item measures. These measures avoid repeated and redundant questions, have high face validity and participants generally appreciate their directness (Van Hooff, Geurts, Taris, \& Kompier, 2007). More importantly, several studies have also demonstrated that multiple-item questionnaires can often be validly replaced by singleitem measures (e.g., Elo, Leppänen, \& Jahkola, 2003; Fisher et al., 2016; Heistaro, Jousilahti, Lahelma, Vartiainen, \& Puska, 2001; Idler \& Benyamini, 1997). Some constructs (i.e., restoration and fatigue) were assessed with SMS questionnaires on pre-defined time points during the day. As the amount of questions to be answered via SMS was limited due to participants' time constraints during the working day and the programming costs for each SMS question, some constructs (i.e., recovery experiences and job satisfaction) were assessed retrospectively with paper-pencil questionnaires filled out in the evening after work (see Figure 1).

\subsubsection{Manipulation check}

Before and after the daily lunch break intervention, participants in the intervention groups reported their level of tension on a scale from 0 to 100 on paper. The scale was anchored: $0=$ extremely relaxed, such as sitting on the couch after exercising and having a sauna bath, $50=$ normal level of relaxation/tension, 100 = extremely tense, such as before a major, stressful life event or an important verbal appearance in public. 


\subsubsection{Recovery experiences during lunch breaks}

We measured three types of recovery experiences during lunch breaks with the help of a paperand-pencil booklet filled out in the evening after work. Relaxation during the lunch break was assessed with the item "During my lunch break, I took time for leisure". To assess levels of psychological detachment during the lunch break, participants reacted to the statement "During my lunch break, I distanced myself from my work". These items stem from the Recovery Experience Questionnaire (Sonnentag \& Fritz, 2007; for a Finnish translation and validation of the REQ, see Kinnunen, Feldt, Siltaloppi, \& Sonnentag, 2011) and were adapted to the lunch break setting (instead of off-job time). Employees' enjoyment of the lunch break was assessed with the item "I enjoyed my lunch break" (for studies using similar items, see Demerouti, Bakker, Sonnentag, \& Fullagar, 2012; Trougakos, Beal, Green, \& Weiss, 2008). For each experience measured, the response scale ranged from 1 (totally disagree) to 5 (totally agree).

\subsubsection{Recovery outcomes}

We measured three aspects of well-being by SMS or paper-and-pencil questionnaires. Restoration was assessed by SMS twice a day: after lunch and in the evening. Participants reported their level of agreement with the statements "Right now, after my lunch break/before going to bed, I feel restored and relaxed" (Demerouti et al., 2012; Ryan \& Frederick, 1997). Fatigue was assessed with the item (Van Hooff et al., 2007): "Right now, after my lunch break/at the end of my work day/before going to bed, I feel fatigued" three times per day (after lunch, afternoon, evening) via SMS. All SMS statements were measured on a scale ranging from 1 (totally disagree) to 7 (totally agree). Job satisfaction was measured with a paper-and -pencil questionnaire completed in the evening after work. The statement was "Today at work I enjoyed working" and was rated on a scale from 1 (totally disagree) to 5 (totally agree) (for a discussion on one-item indicators to 
measure job satisfaction, see Wanous, Reichers, \& Hudy, 1997; Warr, Bindl, Parker, \& Inceoglu, 2014).

\subsection{Statistical analyses}

It turned out that the results of the spring and the fall RCT differed considerably. Therefore, the results are presented separately. First, we present preliminary analyses (i.e., missing data mechanisms, time trends, systematic differences within measurement weeks) using all eight measurements. As in these preliminary analyses no systematic differences within measurement weeks could be detected and we were not interested in changes in recovery and well-being within the weeks before, during and after the intervention, we tested our hypotheses averaging the reported values in the week(s) before (T1), during (T2) and after the intervention period (T3).

In analyzing the data, we combined classical inferential statistics with effect size calculations. Concerning changes across time in the three different groups, we first applied repeated measures ANOVAs. We calculated main effects of time $(T 1, T 2, T 3)$, and group (park walking, relaxation, and control group), and the group $x$ time interactions. These interaction terms revealed whether recovery experiences and outcomes developed differently for the three groups. As we expected different developments in the intervention groups and in the control group, the interaction terms constitute the most important outcomes of these analyses.

We also calculated effect sizes (e.g., Cohen, 1990; Kline, 2004; Sullivan \& Feinn, 2012) using Cohen's $d$ for paired observations for changes in recovery experiences and outcomes during and after the intervention period within the three groups, using the following formula:

$\frac{\text { Mean T1-Mean T2 }}{\text { Std pooled } \sqrt{2 *(1-r T 1 T 2)}}$ (Cohen, 1988, p. 46). Changes in recovery experiences and well-being outcomes at baseline compared to the intervention period are referred to as "intervention effects" and comparisons of baseline versus the week after the intervention period are referred to as "post-intervention effects". Effect sizes smaller than 0.2 were considered trivial, d's between 0.2 
and 0.5 were defined as small, d's between 0.5 and 0.8 were considered medium and d's greater than 0.8 were interpreted as large effect sizes (Cohen, 1992; Sullivan \& Feinn, 2012). We use negative effect sizes ( - ) to indicate a decrease in recovery experiences or outcomes. In addition, we conducted planned contrast analyses to compare specific measurement occasions based on our a priori hypotheses (and to reduce familywise error).

\section{Results}

\subsection{Manipulation check}

During the spring RCT, $76 \%$ of the participants in the intervention groups engaged in relaxation or park walking during their lunch break at least eight times. On average, participants engaged in park walking/relaxation for 8.5 out of ten times during the intervention period. For the park walking group, lunch breaks lasted 29 minutes, of which 15 minutes (range 8-19) were spent in the park. Participants in the relaxation group had a lunch break of 30 minutes, during which they engaged in relaxation exercises for 14 minutes (range 10-20). For the control group, the lunch break lasted 27 minutes (range 8-60). There was no significant difference in the duration of the lunch breaks of the three groups $[F(2,80)=0.86, p=.90]$. For the participants in the two intervention groups, levels of tension decreased significantly after the lunch break on each of the ten intervention days ( $t$-values varied from 3.08 to 6.33 , all $p$-values $<.05$ ). Across the ten days reported levels of tension decreased from an average of 59.2 before lunch to an average of 45.1 after lunch in the park walking group. The relaxation group reported an average change in tension from 56.3 before lunch to 36.6 after lunch.

During the fall $\mathrm{RCT}, 72 \%$ of the participants in the intervention groups engaged in relaxation or park walking during their lunch break at least eight times. On average, participants engaged in park walking/relaxation 8.6 out of ten times during the intervention period. For the park walking 
group, the lunch break lasted 39 minutes, of which 15 minutes (range 12-20) were spent in the park. Participants in the relaxation group took a lunch break of 35 minutes and engaged in relaxation exercises for 13 minutes (range 8-18). For the control group, the lunch break lasted 25 minutes (range 0-40). The duration of the lunch break differed between the three groups $[F(2,67)$ $=13.80, p<.001]$. Post-hoc tests with Bonferroni correction to account for multiple comparisons showed that the lunch breaks of the park walking and also of the relaxation group were significantly longer than the lunch breaks of the control group ( $p$-values $<.05)$. For the participants in the intervention groups, levels of tension significantly decreased after the lunch break during each of the ten intervention days ( $t$-values varied from 2.91 to 6.24 , all $p$-values $<.05$ ). Across the ten days reported levels of tension decreased from 53.9 before lunch to 38.3 after lunch in the park walking group. The relaxation group reported a change in tension from an average of 60.8 before lunch to an average of 44.7 after lunch.

Summing up, adherence to the study protocol was very high. On a daily level, 76 to 96 percent of the participants in the intervention groups engaged in park walking/relaxation. During the intervention period, lunch breaks were on average four minutes longer in fall than in spring $[F(1,150)=8.68, p<.01]$ and seven minutes longer in the intervention groups than in the control groups $[F(1,151)=5.45, p=.02]$. Park walks lasted one minute longer than the relaxation exercises $[F(1,88)=15.2, p<.01]$. There were no differences in the number of times participants engaged in park walking or relaxation exercises $[F(1,95)=0.04, p=.84]$. Levels of tension before and after the lunch break were also very similar in the two intervention groups $[F(1,79)=0.17-0.38, p$-values > $.10]$, and also during the spring and the fall $\operatorname{RCTs}[F(1,79)=0.01-0.06, p$-values $>.10]$.

\subsection{Preliminary analyses using eight measurement days}

To get a better understanding of the changes across time in the recovery experiences and outcomes and to make sure that we did not miss any systematic patterns in the development of 
recovery experiences and well-being within each week under investigation, we first studied participants' means and time trends across the eight measurement days which formed the basis of our study.

With eight measurement days, total missing value rate was $15 \%$. Each day, this rate varied between 3-33\%. Variables measured with paper-and-pencil questionnaires had fewer missing values than variables measured via SMS questionnaires. For variables assessed via SMS, measures were often missing as pairs (indicating that the whole measurement occasion was skipped). It was also obvious that some participants had more than average adherence problems and missing values. For single participants, missing value rate varied between $0-76 \%$ (mean: $10 \%$ ) and was independent of the intervention group (Kruskal-Wallis rank sum test, $p=.36$ ). The missing data mechanism was MAR (Missing At Random), meaning that missing data were unrelated to the specific missing values that should have been obtained (Enders, 2010).

As missing data drastically reduced the sample size in repeated measures analyses due to listwise deletion, we imputed the missing data using the R package "Mice". Mice generates multiple imputations by chained equations in which each variable is imputed based on its own specific model. The values of iterations are drawn from the conditional densities for each variable with the help of the Markov Chain Monte Carlo (MCMC) algorithm. We selected a general-purpose semi-parametric predictive mean matching method $(\mathrm{pmm})$ which preserves optional non-linear relations and accepts only observed data values (Van Buuren \& Groothuis-Oudshoorn, 2011). Imputed values were slightly smaller than the original values. The average difference between original and imputed values was -0.03 (max: 0.05 ) for variables in the paper-and-pencil questionnaires and -0.02 (max: 0.19) for variables assessed via SMS.

In the next step, we checked potential time trends within the intervention period using the imputed data set. Means across the whole time period (i.e., T1-T8) for recovery experiences and 
well-being are displayed in Appendix 1 and 2. Repeated measures ANOVA's to analyze trends within the intervention period (T3-T6) showed that in the spring $R C T$, the values of recovery experiences and outcomes did not differ from each other ( $F$-values varied between 0.22 and 2.73; all $p$-values $\geq .05)$. The only exception was enjoyment of lunch breaks $(F(3,80)=3.35, p=.02)$ for which the third measurement occasion during the intervention period was lower than the second and fourth. Within-subjects contrasts further demonstrated that there were no linear time trends across the four measurement occasions during the intervention period ( $F$-values varied between 0.00 and 0.36 ; all $p$-values $\geq .05)$. In the fall RCT, there were no differences in any of the recovery and well-being indicators measured repeatedly during the intervention period ( $F$-values varied between 0.08 and 1.37 ; all $p$-values $\geq .05$ ). There was only one linear, but declining, time trend for enjoyment of lunch breaks in the park walking group. Overall, differences in recovery experiences and outcomes within the intervention period were negligible. The only linear time trend found was opposite to the logical assumption that positive intervention effects might accumulate over time, indicative of linear dose-response relationships.

Paired-samples $t$-tests for the measurements on Tuesday and on Thursday in the week before (T1) and after the intervention (T3) showed no significant differences in the spring and the fall RCT either: $t$-values varied between -2.45 and 1.72 , and all $p$-values were $>.01$ (Bonferroni corrected for four comparisons).

Summing up, these preliminary analyses directed us to use an approach where we averaged measures on several days before, during and after the intervention without losing information. Using an aggregate of several measurements to create a robust index for a person's well-being which is representative for a longer time span is a common approach in diary research (Binnewies \& Sonnentag, 2013). Aggregation reduces situation-specific influences, balances out minor fluctuations in well-being (e.g., Reis \& Gable, 2000) and minimizes within-person missing data. 
Using the non-imputed data set, means and standard deviations of the study variables for the three groups for the period before (T1), during (T2) and after the intervention period (T3) are presented in Table II.

\subsection{Hypotheses testing, spring}

First, repeated measures ANOVAs showed (Table III) that none of the group $x$ time interaction terms were significant.

\subsubsection{Intervention effect, spring}

Regarding recovery experiences (i.e., relaxation, detachment, and enjoyment) during lunch breaks the changes during the intervention period in the two intervention groups were trivial, effect sizes being less than 0.15 (Table IV). Well-being (i.e., restoration and fatigue) during lunch breaks improved in all groups and, contrary to expectations, particularly in the control group $(d=0.42)$. Unexpectedly, the greatest improvement was found for restoration in the control group $(d=0.47)$. At the end of the afternoon both the relaxation group and the control group experienced somewhat higher levels of well-being. The relaxation group was significantly more satisfied with their work than before the intervention $(d=0.65)$, and more satisfied during the intervention than the control group $(p=.02)$. The relaxation group also felt less fatigued than before the intervention $(d=0.37)$. Well-being in the park walking group remained relatively constant. The relaxation group reported somewhat lower levels of well-being in the evenings than before the intervention period, on average $(d=-0.27)$, while the park walking and the control group reported levels like those at baseline. There was a steep, significant decline in evening restoration in the relaxation group $(d=-0.54)$ compared to levels before the intervention. Averaging well-being across all measurement occasions of the working day and recovery experiences during lunch breaks, the changes in recovery experiences and well-being outcomes were trivial in every group. 


\subsubsection{Post-intervention effect, spring}

After the intervention period the park walking group reported slightly lower levels of enjoyment of their lunch breaks $(d=-0.38)$. The relaxation group experienced somewhat higher levels of detachment $(d=0.20)$ than before the intervention period. The control group's recovery experiences during lunch breaks were the same as before $(d=-0.04)$. Concerning well-being outcomes, only the park walking group reported a positive change in restoration $(d=0.23)$ after lunch compared to baseline. All other changes after the lunch break were trivial in terms of effect sizes. In afternoons and evenings there were only three meaningful changes regarding well-being. Contrary to expectations, participants in the park walking group reported an increase in fatigue at the end of the afternoon $(d=-0.22)$ and the relaxation group experienced lower restoration in the evening compared to baseline $(d=-0.18)$. In the evening the relaxation group experienced lower levels of fatigue $(d=0.25)$ than before the intervention. Across all time points of the working day, recovery experiences and outcomes in the week after the intervention were fairly similar to levels before the intervention in the three groups with average effect sizes around zero.

\subsubsection{Summary}

Overall, employees engaging in park walking and relaxation exercises reported levels of relaxation, detachment, and enjoyment of their lunch breaks throughout the intervention period to be quite similar to baseline. Concerning well-being outcomes, park walking was paradoxically associated with less fatigue after lunch but more fatigue in the afternoon (compared to baseline). Relaxation exercises were associated with higher levels of well-being immediately after the lunch break and at the end of the afternoon during the intervention compared to the period before the intervention. Participants in the relaxation group also reported higher levels of job satisfaction during the intervention period than before, and higher levels of job satisfaction during the intervention period than the control group. However, restoration in the evening was lower during 
the intervention period for this group. Across all measurement occasions, improvements during the intervention period were similar or even greater in the control group than in the intervention groups. Overall, the few small positive effects in the two intervention groups did not persist in the week after the intervention. Park walking and relaxation exercises had similarly small effects on recovery experiences and outcomes that appeared mostly right after the lunch break. An overview of the findings can also be found in Appendix 3.

\subsection{Hypotheses testing, fall}

There were three significant interaction terms of group $x$ time, namely for detachment and enjoyment of the lunch break and for fatigue at the end of the afternoon (Table III). The interaction effect for relaxation was marginally significant. The nature of these interactions will become clear in the following detailed description of the changes across time with in the three groups.

\subsubsection{Intervention effect, fall}

During the intervention period, the greatest changes concerning recovery experiences after lunch break were seen in the park walking group (see Table IV). For the park walking group, levels of relaxation $(d=0.66)$, detachment $(d=0.61)$, and enjoyment of the break $(d=0.47)$ increased notably and significantly compared to baseline and compared to the control group (all $p$-values < .05). The relaxation group experienced a considerable and significant increase in relaxation compared to baseline $(d=0.61)$, but detachment and enjoyment of the lunch breaks were comparable to baseline for this group. Enjoyment of lunch breaks decreased slightly in the control group $(d=-0.26)$. Furthermore, well-being during lunch breaks and at the end of the afternoon improved in the two intervention groups (i.e., higher restoration and lower fatigue, $d=0.30-0.58$ ) while fatigue increased in the control group during lunch breaks $(d=-0.22)$. At the end of the afternoon participants in the park walking were more satisfied with their jobs $(d=0.22)$ and felt 
significantly less fatigued than at baseline $(d=-0.54)$. Participants in the relaxation group felt also less fatigued than before the intervention $(d=0.37)$ and were significantly more satisfied about their jobs $(d=0.52)$. The average well-being in the control group remained stable $(d=0.02)$. In the evenings, participants who engaged in park walking during their lunch break reported higher levels of restoration ( $d=0.26)$ than at baseline. Participants in the relaxation and the control group reported levels of well-being similar to those before the intervention. Fatigue increased in the control group $(d=-0.25)$. Across all measurements of the working day the well-being of the park walking and relaxation groups improved, whereas it remained stable in the control group, average effect sizes being 0.39 (park walking), 0.27 (relaxation) and - 0.07 (control).

\subsubsection{Post-intervention effect, fall}

After the intervention period participants in the control group reported levels of enjoyment of their lunch breaks slightly lower than before the intervention ( $d=-0.24$; see Table IV). For the relaxation group, it was more difficult to detach from work during lunch breaks than at baseline ( $d$ $=-0.52$ ). For the park walking group there were no meaningful differences compared to baseline. Concerning well-being after lunch (i.e., restoration, fatigue), the differences from baseline were trivial for all groups. Only restoration was slightly higher in the relaxation group after the intervention than before $(d=0.20)$. At the end of the afternoon fatigue significantly decreased in the park walking group $(d=0.29)$ compared to baseline. In the relaxation and the control groups, fatigue increased ( $d=-0.31$ and -0.30 respectively). Job satisfaction was the same after the intervention period as before for all groups. In the evening participants in the park walking group again reported slightly improved well-being $(d=0.13$ and 0.24$)$, whereas the relaxation and the control groups' well-being was somewhat lower than at baseline. There was a significant decrease in evening restoration in the relaxation group $(d=-0.27)$. Averaging across all time points of the working day, recovery experiences and outcomes in the week after the intervention were slightly 
higher for the park walking group $(d=0.10)$, and similar to baseline for the relaxation group ( $d=$ $0.08)$ and for the control group $(d=-0.05)$.

\subsubsection{Summary}

Overall, employees engaging in park walking and relaxation exercises in the fall RCT reported more positive recovery experiences and well-being outcomes during the intervention period than before the intervention period, and compared to the control group. Park walking in particular was linked to improvements in recovery experiences and recovery outcomes across all measurement occasions during the working day compared to baseline. Park walks were also related to better recovery experiences and lower fatigue in the afternoon during the intervention period compared to the control group. Relaxation exercises were related to higher levels of well-being directly after the lunch break and at the end of the afternoon during the intervention period compared to baseline. After the intervention period had ended, recovery experiences and well-being outcomes were similar to baseline in the two intervention groups and also in the control group. For the park walking group some beneficial effects (i.e., lower fatigue) seemed to persist during the week after the intervention while the relaxation group felt as before the intervention. An overview of the findings can also be found in Appendix 3.

\subsection{Additional post-hoc analyses}

After analyzing and interpreting the results, we tested several explanations for the absence of (strong) positive effects of park walking and relaxation exercises on recovery experiences and outcomes as well as for the unexpected differential effects for the spring and fall intervention. We took into account those variables in which the intervention groups differed (i.e., lunch break length during the intervention) and the variables in which the spring and fall samples differed (i.e., age and exhaustion). 


\subsubsection{Lunch break length during the intervention}

The length of the lunch breaks differed between the intervention groups in the fall sample (with shorter breaks in the control group). Therefore, we examined this variable more closely in the fall data. Average lunch break length showed only few significant connections to recovery experiences and outcomes during the intervention period. Three-way interactions, i.e., time $(T 1, T 2, T 3) x$ group (park walking, relaxation, control) x lunch break length during intervention, were nonsignificant. It seemed that the length of the lunch break did not matter for changes in recovery and well-being across the intervention period in the three intervention groups.

\subsubsection{Age and exhaustion at baseline}

Participants in the spring and the fall intervention differed from each other concerning age and exhaustion at baseline. Even though there were no differences concerning these variables between the intervention groups (either in the spring or fall samples), we examined whether different age groups or people with high or low levels of exhaustion reported different effects on their recovery experiences and well-being across the intervention period. We conducted threeway interactions, i.e., time $(\mathrm{T} 1, \mathrm{~T} 2, \mathrm{~T} 3) \mathrm{x}$ group (park walking, relaxation, control) $\mathrm{x}$ age/exhaustion, to test whether the development across time was different in the three groups and dependent on participants' age or baseline level of exhaustion.

In the spring RCT, of the nine outcomes tested, two showed significant interaction effects for lunchtime restoration $(F(4,136)=2.81 ; p=.03)$ and afternoon fatigue $(F(4,136)=3.42 ; p=.01)$. The rise in restoration during lunch breaks was greater for older participants (52-62 years) in the walking group whereas younger participants (28-51 years) in the relaxation group benefitted more from this exercise during the intervention period. Fatigue in the afternoon improved more during the intervention period for older workers in the park walking group than for younger workers. These interactions suggest that park walking seems slightly more beneficial for older than for 
younger workers. Concerning exhaustion at baseline, none of the tested interaction terms were significant. In the fall RCT, none of the interaction terms (time $\mathrm{x}$ group $\mathrm{x}$ age/exhaustion) were significant, implying that beneficial intervention effects were probably not dependent on age or baseline levels of exhaustion.

\subsubsection{Autonomy during lunch breaks and enjoyment}

If participants feel compelled to engage in a certain activity, one could expect that the pleasure in this activity would also be reduced (see Trougakos et al., 2013). However, this did not seem to be the case. Enjoyment of lunch breaks was the same during the intervention period for the three groups $[F(2,150)=1.82, p=.17]$ and significantly increased for the park walking group during the intervention period in fall. So, even when not being able to decide which lunch break activity to pursue (due to randomization), participants in the park walking and the relaxation group enjoyed their lunch breaks as much as did participants in the control group who could freely decide what to do.

\section{Discussion}

This study was designed to investigate the effects of park walking and relaxation exercises during lunch breaks on employees' recovery experiences and outcomes during the working day. While 56 people continued their usual lunchtime routines, 51 took a short park walk and 46 did relaxation exercises during their lunch breaks for ten consecutive working days. The study was split into two identical RCTs conducted in spring $(N=83)$ and in fall $(N=70)$ in 2014. Thus, the RCT in fall replicated the RCT conducted in spring. An interesting but unexpected result of the two RCTs concerns the striking differences seen between the effects of the intervention carried out in the two different seasons. 


\subsection{Effects of spring RCT}

In the spring RCT, park walking and relaxation exercises had similar, but rather inconsistent and minor effects on recovery experiences and well-being outcomes. Thus, considering the findings of the spring RCT, our hypotheses regarding positive, persisting effects both on recovery experiences and well-being outcomes, were not supported. Recovery experiences hardly changed for the intervention groups and well-being improved only slightly and briefly, mainly immediately after the lunch break, supporting our hypothesis that strongest effects on well-being will be found immediately after the lunch break (rather than in the afternoon or evening). In addition, unexpected positive changes occurred in the control group. Across all measurement occasions of the working day, improvements were greatest for the control group, which was contrary to our hypotheses (assuming larger effects for the intervention groups).

\subsection{Effects of fall RCT}

By contrast, a clear picture emerged in the fall RCT. Both relaxation exercises and park walking during lunch breaks were associated with positive changes in recovery experiences during lunch breaks, and in well-being during the intervention period (compared to baseline and the control group). Accordingly, our hypotheses were supported in the fall RCT. The strongest effects were found immediately after the lunch break. The effects on recovery experiences and well-being generally lasted only for the duration of the intervention period itself, meaning that our hypothesis regarding persisting effects after the intervention period was not supported. The most consistently positive findings were related to park walking. Park walking was associated with small to medium improvements in well-being throughout the working day. The relaxation group reported higher levels of well-being after lunch and at the end of the afternoon during the intervention period than at baseline. Detachment during lunch breaks and enjoyment of one's lunch breaks in the intervention weeks were slightly better for the park walking than for the 
relaxation group. Relaxation during lunch breaks was similar in the two intervention groups. Contrary to the spring RCT (but in line with our hypotheses), recovery experiences and outcomes of the control group remained stable and were less favorable than for both intervention groups.

\subsection{Explanations for differential effects in spring and fall RCT}

How can the differences between the results of the RCT's in different seasons be explained? Firstly, initial differences between the spring and fall samples in terms of work sector, age, and exhaustion deserve some consideration. In the fall intervention, about half of the sample were teachers, whereas the sample was more diverse in the spring intervention. It is possible that intervention effects are more consistent among more homogenous groups of workers. Regarding age, some studies have suggested that it takes older workers longer to recover from job stress (e.g., Kiss, De Meester, \& Braeckman, 2008; Mohren, Jansen, \& Kant, 2010) and the spring RCT, including slightly older participants, suggests that age may affect the efficiency of workplace health interventions. Our additional analyses suggest that older workers may benefit more from park walking than from very brief relaxation exercises. Yet it should be noted that the differences in age between spring and fall were small ( 49 compared to 46 years on average) and there were no differences in age between the intervention groups within the seasons. More future research on the role of age is needed.

Regarding exhaustion, it may be that employees with higher baseline levels of exhaustion (in spring) need more time to recover and therefore a longer intervention to achieve improvements than people with lower levels of exhaustion (in fall). Exhaustion is also associated with decreases in cognitive control and flexible thinking (Van der Linden, Frese, \& Meijman, 2003). If participants feel more exhausted, changing their lunch routines may be more difficult and demanding to them. Consequently, it may take longer time before behavioral interventions changing lunch routines can 
fully unfold their positive effects in exhausted workers. However, our additional analyses did not point to any differences in beneficial intervention effects based on baseline levels of exhaustion.

Another interesting difference between the two RCTs in spring and fall concerns the length of the lunch breaks during the intervention period. Whereas the lunch break lasted around 30 minutes for all participants in the spring RCT, the lunch breaks were longer for the intervention groups than for the control group in the fall RCT. The longest lunch break (39 minutes) was reported by the park walking group. The relaxation group also enjoyed a break which was about 10 minutes longer than the break of the control group. Although the break length was congruent with the pattern of effects found (i.e., the most consistent, beneficial effects were found for the park walking group who also had the longest lunch break) the additional post-hoc analyses suggest that merely taking longer breaks does not suffice to explain the differential effects of the spring and fall RCT, nor does it seem to be a good strategy to increase the benefits of lunch breaks. In general, lunch breaks during the intervention weeks were rather short (30-40 minutes), meaning that participants in the intervention groups ate lunch in 15 to 25 minutes. As their usual lunch break was about 30 minutes before the intervention (see Table I), this implies that most people ate more hastily than usual during the intervention period. This may undo or reduce potential positive effects of relaxation or park walking.

Another difference between the spring and fall RCT concerns the weather conditions. Even though the weather during both seasons was pretty good (with an average temperature of $15{ }^{\circ} \mathrm{C}$ in spring and $14^{\circ} \mathrm{C}$ in fall during lunch break time, no precipitation and mostly sunshine), the weather during the second intervention week in spring was very good for this time of the year (i.e., sunny and daily temperatures of up to $28^{\circ} \mathrm{C}$ ), potentially uplifting participants' well-being. This may be especially true for people spending more time outside, that is, for the park walking group. However, despite popular beliefs, earlier studies on weather and well-being found generally no or 
only very weak associations between various weather parameters and mood (e.g., Klimstra et al., 2001; Lucas \& Lawless, 2013). Keller et al. (2005) found that spending more time outdoors was more strongly related to increased positive mood during nice weather in spring time. This seems opposite to what we found in our intervention study: during exceptionally nice weather in spring time, park walking had fewer effects on well-being than park walking during fall. The good weather does not either explain why particularly the control group improved in the spring RCT as all participants experienced the nice weather conditions simultaneously.

Another explanation for more pronounced beneficial effects in fall than in spring may be "compensatory rivalry" occurring mainly in the spring intervention, when the study was novel in all companies. Compensatory rivalry may arise if the control group in an experimental setting feels disappointed or disadvantaged at not receiving experimental treatment and accordingly changes behavior or its assessment of a situation (Conrad \& Conrad, 2005). This explanation is also somewhat in line with answers in a discussion group and to a digital inquiry we made after the intervention. Some people in the control group stated that participation in the study made them more aware of their lunch break activities. Others reported that they talked about the activities of the intervention groups and that they reminded each other not to talk about work during their breaks, because it might "ruin recovery during their lunch break". Thus, some spillover from the intervention groups to the control groups may have occurred. In light of our digital inquiry after the intervention study was finished, we can rule out that the control group changed their lunch break routines (e.g., taking longer breaks, leaving the workplace etc.). It also remains unclear why or how these processes may have affected the control group in the spring but not in the fall intervention. 


\subsection{Park walking versus relaxation exercises during lunch breaks}

The findings for the park walking group were most consistently positive across the two RCTs and across the working day in the fall RCT. It seems that participants in the park walking group reported slightly higher levels of psychological detachment from their work during their lunch breaks than did the people in the relaxation group. In fall, the increase in enjoyment of the break during the intervention period was also greater for the park walking group than for the relaxation group. Physical exercise is one of the most efficient treatment methods in behavioral medicine (Penedo \& Dahn, 2005) and combining it with immersion in natural environments seems a promising approach in occupational health care.

For the relaxation group the changes in recovery experiences during the intervention period were slightly less pronounced. Only in spring was the increase in relaxation during the lunch breaks somewhat greater for the relaxation group than for the park walking group. It is possible that it simply takes more time to learn relaxation techniques than to enjoy a park walk. Some participants also reported that they would have preferred audio instructions (instead of written instructions) for the relaxation exercises during the intervention weeks. Despite this, those who took part in the relaxation exercises continued their exercises after the intervention period more often than those taking part in park walking. On $10 \%$ of the 194 days covered by the postintervention analyses ( 2 measurements and 97 people), participants continued with the relaxation exercises, compared to only $3 \%$ for the park walking group. This could either mean that the participants enjoyed the relaxation exercises or that they felt that they had not yet fully mastered the relaxation exercises and wanted to continue learning them.

The enhanced levels of well-being across the working day (even in the evenings) for the park walking group may suggest that positively experienced lunch breaks may buffer job stress and preserve working people's well-being throughout the working day. This corroborates recovery 
theories and earlier research findings regarding the link between work breaks, recovery experiences, and recovery outcomes (Fritz, Ellis, Demsky, Lin, \& Guros, 2013; Trougakos et al., 2008; Trougakos \& Hideg, 2009). Future research could focus on these questions in more detail.

Park walking as a rather active use of free time during lunch breaks seemed to serve both recovery mechanisms as it reduced demands (as evident in increases in relaxation and detachment) and created resources (as evident in an increase in enjoyment of lunch breaks). Relaxation exercises seemed to mainly serve reduction of demands (as evident in increased relaxation, but not in detachment and enjoyment). Both park walks and relaxation exercises offered a break free from work demands, thereby facilitating reduction of demands or passive recovery from work as explained in the effort-recovery model (Meijman \& Mulder, 1998). Furthermore, both lunch break activities affected well-being positively allowing employees to replenish and create internal resources, fueling the active recovery mechanism in line with the conservation of resources theory (Hobfoll \& Shirom, 2001). Nonetheless, they also raise interesting questions and potential areas for future research regarding the interplay and importance of the two assumed recovery mechanisms such as: Is demand reduction a precondition for creation of resources? Are the mechanisms additive or interactive? And how could it be that the effects of lunch break activities on recovery experiences varied by the season? What are the minimum ingredients for a lunch break to achieve detachment, relaxation and enjoyment?

\subsection{Limitations and recommendations for future research}

Our study demonstrated that interventions in organizational settings are challenging to conduct. Firstly, we deliberately chose a setup in which each organization included both intervention groups and a control group to ensure that potential effects found were more likely due to the intervention and not the type of organization in which the participants were employed. However, 
some spillover from the intervention groups to the control group is possible. Even merely telling participants that a study is focusing on "recovery from work during lunch breaks" may influence people's behavior. However, it is unrealistic and unethical to ask employees to sacrifice their time and energy to an intervention without knowing its goal.

Secondly, the sample consisted mainly of highly educated, female knowledge workers. Welleducated female dominated samples are common in organizational research and a recent study has found very similar treatment effects in convenience samples compared to nationally representative population-based samples (Mullinix, Leeper, Druckman, \& Freese, 2015). Nevertheless, the composition of our sample limits the external validity of our findings and it is not clear whether similar effects would emerge in other, more heterogeneous groups of workers such as manual, physically active workers or men working in male dominated sectors.

Thirdly, the intervention period in this study was rather short (two weeks). If a person engaged in park walking or relaxation exercises, behavior was changed for merely 150 minutes (15 minutes on 10 days) across a time span of two weeks. Future RCTs with longer intervention periods may achieve stronger and longer lasting effects. For instance, it usually requires 70 to 120 repetitions and approximately six weeks of training for applied relaxation techniques to become an everyday, well-rehearsed skill and achieve permanent changes (Öst, 1987). Research on the formation of habits has also demonstrated that it may take 18 to 254 days for a new behavior to become a routine (Lally, Van Jaarsveld, Potts, \& Wardle, 2010). Until that time, engaging in new behaviors demands decidedly high levels of self-control (Muraven \& Baumeister, 2000). In combination with a stressful job, forcing oneself to engage in relaxation or park walking during lunch breaks may initially deplete some self-regulatory resources. After reaching a stage of automaticity, less self-control is needed, probably resulting in stronger and longer lasting positive effects. Accordingly, intervention periods of four weeks to three months would be desirable. 
However we are well aware that these interventions are expensive and time consuming. This also prevented us from prolonging the intervention period. In practice, even a two-week intervention period with intensive, repeated daily measurements was challenging to realize.

Fourthly, although we planned the intervention study carefully and were aware of important factors affecting the intervention results, we may have missed some information regarding the context of the intervention (Nielsen \& Abildgaard, 2013). A mixed-methods approach integrating quantitative and qualitative information would be an appropriate approach in this respect.

Fifthly, we found different effects of park walking and relaxation on recovery experiences and outcomes in spring and fall. It is unclear whether these differences were actually due to the season (or to other factors which varied with the season such as the type of companies taking part). Moreover, relaxation exercises and park walking actually represent a complex set of behaviors which may affect employees' well-being. For instance, in addition to relaxation exercises, employees may also have spent more time in a quiet surrounding. Park walking entails perceiving nature with various senses as well as light physical activity. At this stage, we cannot disentangle what the most beneficial ingredients of these lunch break activities were.

Sixthly, numerous studies have demonstrated that employees who need worksite health promotion programs the most are less likely to participate and drop out more frequently than people with lower stress levels and fewer health complaints (Robroek, van Lenthe, van Empelen, \& Burdorf, 2009; Toker, Heaney, \& Ein-Gar, 2015). The lower exhaustion levels in our final samples compared to the initial sample also point into this direction. More intensive (i.e., longer lasting) studies in more exhausted/stressed populations may uncover more beneficial effects of lunch breaks interventions.

Last but not least, despite the fact that our post-hoc analyses showed that participants generally enjoyed their lunch break (irrespective of the group they were assigned to), future 
intervention studies on lunch break activities could add a fourth group which can freely decide which activity they would like to engage in during their break. As control over break activities is a key element in recovering from stress (Trougakos, Hideg, Cheng, \& Beal, 2013), a group which is provided with high autonomy may benefit more from the lunch break than persons who are randomly assigned to an activity.

Our study also demonstrated that practical restrictions due to the realities of working life (in our case the division of the intervention into two parts) can result in extremely interesting findings. If we had conducted only the spring RCT, our conclusions would have been quite different from what they are now. Although it has long been known that interventions in organizational settings are susceptible to influences beyond the researchers' control, we recommend that future research should profit from this, for example, by splitting intervention studies into several parts, carried out during different seasons and in different companies.

\subsection{Conclusions}

In this study, we combined theoretical frameworks from work psychology and environmental psychology to assess and compare the effects of park walking and relaxation exercises during lunch breaks. Even though these break activities were effective in some aspects and have the potential to improve and preserve working people's well-being, the effects on employees' recovery and well-being were of small magnitude and rather short duration. To achieve more lasting effects an intervention longer than two weeks is very likely needed. Both interventions park walking and relaxation exercises - distract attention from the source of stress (e.g., heavy workload, emotional demands, poorly designed work tasks) and instead aim at alleviating individual strain. This may in part account for the relatively short-lived effects. Prolonging the intervention period and combining individual-level lunch break interventions with organizationallevel interventions aimed at lowering job demands and increasing job resources (e.g., van 
Wingerden, Bakker, \& Derks, 2016) may produce longer lasting changes in occupational wellbeing. Park walking and relaxation exercises activities are fairly easy to learn and implement in an organizational setting, and may assist employees in replenishing the resources needed to perform well on the job during the working day. 


\section{References}

Allvin, M., Aronsson, G., Hagström, T., Johansson, G., \& Lundberg, U. (2011). Work without boundaries: psychological perspectives on the new working life. Hoboken, NJ: John Wiley and Sons.

Berman, M. G., Jonides, J., \& Kaplan, S. (2008). The cognitive benefits of interacting with nature. Psychological Science, 19(12), 1207-1212.

Binnewies, C. \& Sonnentag, S. (2013). The application of diary methods to examine workers' daily recovery during off-job time. In A. B. Bakker \& K. Daniels (Eds.), A day in the life of a happy worker (pp. 72-84). Hove: Psychology Press.

Bowler, D. E., Buyung-Ali, L. M., Knight, T. M., \& Pullin, A. S. (2010). A systematic review of evidence for the added benefits to health of exposure to natural environments. BMC Public Health, 10(1), 456. doi: doi:10.1186/1471-2458-10-456

Brosschot, J. F., Gerin, W., \& Thayer, J. F. (2006). The perseverative cognition hypothesis: A review of worry, prolonged stress-related physiological activation, and health. Journal of Psychosomatic Research, 60(2), 113-124.

Brown, D. K., Barton, J. L., Pretty, J., \& Gladwell, V. F. (2014). Walks4Work: Assessing the role of the natural environment in a workplace physical activity intervention. Scandinavian Journal of Work, Environment \& Health, 40(4), 390-399. doi: 10.5271/sjweh.3421

Brown, K.W., \& Ryan, R.M. (2003). The benefits of being present: Mindfulness and its role in psychological well-being. Journal of Personality and Social Psychology, 84(4), 822-848.

Chang, C.-Y., Hammitt, W. E., Chen, P.-K., Machnik, L., \& Su, W.-C. (2008). Psychophysiological responses and restorative values of natural environments in Taiwan. Landscape and Urban Planning, 85(2), 79-84. 
Cohen, J. (1988). Statistical power analysis for the behavioral sciences. Hillsdale (NJ): Lawrence Erlbaum Associates.

Cohen, J. (1990). Things I have learned (so far). American Psychologist, 45(12), 1304. doi: 10.1037/0003-066X.45.12.1304

Cohen, J. (1992). A power primer. Psychological Bulletin, 112(1), 155-159.

Conrad, K. M., \& Conrad, K. J. (2005). Compensatory rivalry. In B. Everitt \& D. Howell (Eds.), Encyclopedia of Statistics in Behavioral Science. Hoboken: John Wiley \& Sons, Ltd.

Dart, J. (2006). Home-based work and leisure spaces: settee or work-station? Leisure Studies, 25(3), 313-328.

De Bloom, J., Kinnunen, U., \& Korpela, K. (2014). Exposure to nature versus relaxation during lunch breaks and recovery from work: development and design of an intervention study to improve workers' health, well-being, work performance and creativity. BMC Public Health, 14.

Demerouti, E., Bakker, A. B., Sonnentag, S., \& Fullagar, C. J. (2012). Work-related flow and energy at work and at home: A study on the role of daily recovery. Journal of Organizational Behavior, 33(2), 276-295.

Elo, A., Leppänen, A., \& Jahkola, A. (2003). Validity of a single-item measure of stress symptoms. Scandinavian Journal of Work, Environment \& Health, 29, 444-451.

Enders, C. K. (2010). Applied missing data analysis. New York: Guilford Press.

Esch, T., Fricchione, G. L., \& Stefano, G. B. (2003). The therapeutic use of the relaxation response in stress-related diseases. Medical Science Monitor, 9(2), 23-34.

Etzion, D., Eden, D., \& Lapidot, Y. (1998). Relief from job stressors and burnout: reserve service as a respite. Journal of Applied Psychology, 8, 577-585. 
Feuerhahn, N., Sonnentag, S., \& Woll, A. (2013). Exercise after work, psychological mediators, and affect: A day-level study. European Journal of Work and Organizational Psychology, 23(1), 62-79.

Fisher, G. G., Matthews, R. A., \& Gibbons, A. M. (2016). Developing and investigating the use of single-item measures in organizational research. Journal of Occupational Health Psychology, 21(1), 3-23.

Flaxman, P. E., \& Bond, F. W. (2010). Worksite stress management training: Moderated effects and clinical significance. Journal of Occupational Health Psychology, 15(4), 347-358.

Fritz, C., Ellis, A. M., Demsky, C. A., Lin, B. C., \& Guros, F. (2013). Embracing work breaks: Recovering from work stress. Organizational Dynamics, 42(4), 274-280.

Geurts, S. A. E., \& Sonnentag, S. (2006). Recovery as an explanatory mechanism in the relation between acute stress reactions and chronic health impairment. Scandinavian Journal of Work, Environment \& Health, 32, 482-492.

Grossman, P., Niemann, L., Schmidt, S., \& Walach, H. (2004). Mindfulness-based stress reduction and health benefits: A meta-analysis. Journal of Psychosomatic Research, 57(1), 35-44.

Hartig, T. (2004). Restorative environments. In C. Spielberger (Ed), Encyclopedia of Applied Psychology (Vol. 3, 273-279). San Diego, CA: Academic Press.

Hartig, T., Evans, G. W., Jamner, L. D., Davis, D. S., \& Gärling, T. (2003). Tracking restoration in natural and urban field settings. Journal of Environmental Psychology, 23(2), 109-123. Hartig, T., Korpela, K., Evans, G.W., \& Gärling, T. (1997). A measure of restorative quality of environments. Scandinavian Housing \& Planning Research, 14, 175-194.

Hartig, T., Mang, M., \& Evans, G. W. (1991). Restorative effects of natural environment experiences. Environment \& Behavior, 23(1), 3-26. 
Hartig, T., Mitchell, R., de Vries, S., \& Frumkin, H. (2014). Nature and health. Annual Review of Public Health, 35, 207-228.

Hayes-Skelton, S. A., Usmani, A., Lee, J. K., Roemer, L., \& Orsillo, S. M. (2012). A fresh look at potential mechanisms of change in applied relaxation for generalized anxiety disorder: A case series. Cognitive \& Behavioral Practice, 19(3), 451-462. doi:

10.1016/j.cbpra.2011.12.005

Heistaro, S., Jousilahti, P., Lahelma, E., Vartiainen, E., \& Puska, P. (2001). Self-rated health and mortality: A long term prospective study in eastern Finland. Journal of Epidemiology and Community Health, 55(4), 227-232.

Hobfoll, S, E., \& Shirom, A. (2001). Conservation of Resources Theory: Applications to stress and management in the workplace. In R. T. Golembiewski (Ed.), Handbook of organizational behavior (Vol. 2nd ed, rev. ed and exp. ed., pp. 57-80). New York: Marcel Dekker.

Hockey, R. (2013). The psychology of fatigue, work effort and control. New York: Cambridge University Press.

Hülsheger, U. R., \& Schewe, A. F. (2011). On the costs and benefits of emotional labor: A metaanalysis of three decades of research. Journal of Occupational Health Psychology, 16(3), 361389.

Hülsheger, U. R., Alberts, H. J., Feinholdt, A., \& Lang, J. W. (2013). Benefits of mindfulness at work: The role of mindfulness in emotion regulation, emotional exhaustion, and job satisfaction. Journal of Applied Psychology, 98(2), 310-325.

Idler, E. L., \& Benyamini, Y. (1997). Self-rated health and mortality: A review of twenty-seven community studies. Journal of Health and Social Behavior, 38(1), 21-37.

Kaplan, S. (1995). The restorative benefits of nature: Toward an integrative framework. Journal of Environmental Psychology, 15(3), 169-182. 
Kaplan, S., \& Berman, M. G. (2010). Directed attention as a common resource for executive functioning and self-regulation. Perspectives on Psychological Science, 5(1), 43-57.

Keller, M. C., Fredrickson, B. L., Ybarra, O., Cote, S., Johnson, K., Mikels, J., ... Wager, T. (2005). A warm heart and a clear head. The contingent effects of weather on mood and cognition. Psychological Science, 16(9), 724-731.

Kinnunen, U., Feldt, T., Siltaloppi, M., \& Sonnentag, S. (2011). Job demands-resources model in the context of recovery: Testing recovery experiences as mediators. European Journal of Work and Organizational Psychology, 20(6), 805-832.

Kiss, P., De Meester, M., \& Braeckman, L. (2008). Differences between younger and older workers in the need for recovery after work. International Archives of Occupational \& Environmental Health, 81(3), 311-320.

Klimstra, T. A., Frijns, T., Keijsers, L., Denissen, J. J., Raaijmakers, Q. A., van Aken, M. A., ... Meeus, W. H. (2011). Come rain or come shine: individual differences in how weather affects mood. Emotion, 11(6), 1495-1499.

Kline, R. B. (2004). Beyond significance testing: Reforming data analysis methods in behavioral research. Washington DC: American Psychological Association.

Korpela, K., \& Kinnunen, U. (2011). How is leisure time interacting with nature related to the need for recovery from work demands? Testing multiple mediators. Leisure Sciences, 33(1), 1-14. Korpela, K., De Bloom, J., \& Kinnunen, U. (2015). From restorative environments to restoration in work. Intelligent Buildings International, 7, 215-223.

Krajewski, J., Sauerland, M., \& Wieland, R. (2011). Relaxation-induced cortisol changes within lunch breaks - an experimental longitudinal worksite field study. Journal of Occupational and Organizational Psychology, 84(2), 382-394. 
Krajewski, J., Wieland, R., \& Sauerland, M. (2010). Regulating strain states by using the recovery potential of lunch breaks. Journal of Occupational Health Psychology, 15(2), 131-139.

Lally, P., Van Jaarsveld, C. H. M., Potts, H. W. W., \& Wardle, J. (2010). How are habits formed? Modelling habit formation in the real world. European Journal of Social Psychology, 40(6), 998-1009.

Lee, K. E., Williams, K. J. H., Sargent, L. D., Williams, N. S. G., \& Johnson, K. A. (2015). 40-second green roof views sustain attention: The role of micro-breaks in attention restoration. Journal of Environmental Psychology, 42, 182-189.

Locke, E. A. (1976). The nature and causes of job satisfaction. In M. D. Dunnette (Ed.), Handbook of industrial and organizational psychology (Vol. 1, pp. 1297-1343). Chicago: Rand McNally.

Lucas, R. E., \& Lawless, N. M. (2013). Does life seem better on a sunny day? Examining the association between daily weather conditions and life satisfaction judgments. Journal of Personality and Social Psychology, 104(5), 872-884.

Marzuq, N., \& Drach-Zahavy, A. (2012). Recovery during a short period of respite: The interactive roles of mindfulness and respite experiences. Work \& Stress, 26(2), 175-194.

McCallie, M. S., Blum, C. M., \& Hood, C. J. (2006). Progressive muscle relaxation. Journal of Human Behavior in the Social Environment, 13(3), 51-66.

Meijman, T. F., \& Mulder, G. (1998). Psychological aspects of workload. In P. J. D. Drenth, H. Thierry \& C. J. de Wolff (Eds.), Handbook of work and organizational psychology (2nd edition). Work psychology (Vol. 2, pp. 5-33). Hove: Psychology Press.

Mohren, D. C. L., Jansen, N. W. H., \& Kant, I. J. (2010). Need for recovery from work in relation to age: A prospective cohort study. International Archives of Occupational \& Environmental Health, 83(5), 553-561. 
Mullinix, K. J., Leeper, T. J., Druckman, J. N., \& Freese, J. (2015). The generalizability of survey experiments. Journal of Experimental Political Science, 2(02), 109-138.

Muraven, M., \& Baumeister, R.F. (2000). Self-regulation and depletion of limited resources: Does self-control resemble a muscle? Psychological Bulletin, 126, 247-259.

Newman, D.A. (2009). Missing data techniques and low response rates. The role of systematic nonresponse parameters. In C. E. Lance \& R. J. Vandenberg (Eds.), Statistical and methodological myths and urban legends. Doctrine, verity and fable in the organizational and social sciences. Hove, East Sussex: Routledge.

Nielsen, K., \& Abildgaard, J. S. (2013). Organizational interventions: A research-based framework for the evaluation of both process and effects. Work \& Stress, 27(3), 278-297.

Nixon, A. E., Mazzola, J. J., Bauer, J., Krueger, J. R., \& Spector, P. E. (2011). Can work make you sick? A meta-analysis of the relationships between job stressors and physical symptoms. Work \& Stress, 25(1), 1-22.

Öst, L.G. (1987). Applied relaxation: Description of a coping technique and review of controlled studies. Behaviour Research and Therapy, 25(5), 397-409.

Park, B. J., Tsunetsugu, Y., Kasetani, T., Kagawa, T., \& Miyazaki, Y. (2010). The physiological effects of Shinrin-yoku (taking in the forest atmosphere or forest bathing): Evidence from field experiments in 24 forests across Japan. Environmental Health and Preventive Medicine, 15(1), 18-26.

Park, Y., Fritz, C., \& Jex, S. M. (2011). Relationships between work-home segmentation and psychological detachment from work: The role of communication technology use at home. Journal of Occupational Health Psychology, 16(4), 457. 
Parsons, R., Tassinary, L. G., Ulrich, R. S., Hebl, M. R., \& Grossman-Alexander, M. (1998). The view from the road: Implications for stress recovery and immunization. Journal of Environmental Psychology, 18(2), 113-140.

Pasanen, T. P., Tyrväinen, L., \& Korpela, K. M. (2014). The relationship between perceived health and physical activity indoors, outdoors in built environments, and outdoors in nature. Applied Psychology: Health and Well-Being, 6(3), 324-346.

Penedo, F. J., \& Dahn, J. R. (2005). Exercise and well-being: A review of mental and physical health benefits associated with physical activity. Current Opinion in Psychiatry, 18(2), 189-193.

Peters, P., den Dulk, L., \& van der Lippe, T. (2009). The effects of time-spatial flexibility and new working conditions on employees' work-life balance: The Dutch case. Community, Work \& Family, 12(3), 279-297.

Pressman, S. D., Matthews, K. A., Cohen, S., Martire, L. M., Scheier, M. F., Baum, A., \& Schulz, R. (2009). Association of enjoyable leisure activities with psychological and physical well-being. Psychosomatic Medicine, 71(7), 725-732.

Ratcliffe, E., Gatersleben, B., \& Sowden, P. T. (2013). Bird sounds and their contributions to perceived attention restoration and stress recovery. Journal of Environmental Psychology, 36, 221-228.

Reed, J., \& Ones, D. S. (2006). The effect of acute aerobic exercise on positive activated affect: A meta-analysis. Psychology of Sport and Exercise, 7, 477-514.

Reis, H. T., \& Gable, S. L. (2000). Event-sampling and other methods for studying everyday experience. In H. T. Reis \& C. M. Judd (Eds.), Handbook of research methods in social and personality psychology (pp. 190-222). Cambridge: Cambridge University Press. 
Richardson, K. M., \& Rothstein, H. R. (2008). Effects of occupational stress management intervention programs: A meta-analysis. Journal of Occupational Health Psychology, 13(1), 69-93.

Robbins, R., \& Wansink, B. (2016). The $10 \%$ solution: Tying managerial salary increases to workplace wellness actions (and not results). Journal of Occupational Health Psychology. doi: 26820808

Robroek, S. J., van Lenthe, F. J., van Empelen, P., \& Burdorf, A. (2009). Determinants of participation in worksite health promotion programmes: a systematic review. International Journal of Behavioral Nutrition and Physical Activity, 6, 26.

Ryan, R. M., \& Frederick, C. (1997). On energy, personality, and health: Subjective vitality as a dynamic reflection of well-being. Journal of Personality, 65(3), 529-565.

Ryan, R. M., Bernstein, J. H., \& Brown, K. W. (2010). Weekends, work, and well-being: Psychological need satisfactions and day of the week effects on mood, vitality, and physical symptoms. Journal of Social and Clinical Psychology, 29(1), 95-122.

Ryan, R. M., Weinstein, N., Bernstein, J., Brown, K. W., Mistretta, L., \& Gagne, M. (2010). Vitalizing effects of being outdoors and in nature. Journal of Environmental Psychology, 30(2), 159168

Schaufeli, W.B., Bakker, A.B., \& Van Rhenen, W. (2009). How changes in job demands and resources predict burnout, work engagement, and sickness absenteeism. Journal of Organizational Behavior, 30(7), 893-917.

Schnieder, S., Stappert, S., Takahashi, M., Fricchione, G. L., Esch, T., \& Krajewski, J. (2013). Sustainable reduction of sleepiness through salutogenic self-care procedure in lunch breaks: A pilot study. Evidence-Based Complementary and Alternative Medicine, 2013. 
Sonnentag, S. (2001). Work, recovery activities, and individual well-being: A diary study. Journal of Occupational Health Psychology, 6, 196-210.

Sonnentag, S., \& Fritz, C. (2007). The recovery experience questionnaire: Development and validation of a measure for assessing recuperation and unwinding from work. Journal of Occupational Health Psychology, 12, 204-221.

Sonnentag, S., \& Fritz, C. (2015). Recovery from job stress: The stressor-detachment model as an integrative framework. Journal of Organizational Behavior, 36(1), 72-103.

Sonnentag, S., \& Zijlstra, F. R. H. (2006). Job characteristics and off-job activities as predictors of need for recovery, well-being, and fatigue. Journal of Applied Psychology, 91(2), 330.

Stone, A. A., Kennedy-Moore, E., \& Neale, J. M. (1995). Association between daily coping and endof-day mood. Health Psychology, 14(4), 341-349.

Sullivan, G. M., \& Feinn, R. (2012). Using effect sizes - or why the p value is not enough. Journal of Graduate Medical Education, 4(3), 279-282.

Tay, L., \& Diener, E. (2011). Needs and subjective well-being around the world. Journal of Personality and Social Psychology, 101(2), 354-365.

Tinsley, H. E. A., \& Eldredge, B. D. (1995). Psychological benefits of leisure participation: A taxonomy of leisure activities based on their need-gratifying properties. Journal of Counseling Psychology, 42(2), 123-132.

Toker, S., Heaney, C. A., \& Ein-Gar, D. (2015). Why won't they participate? Barriers to participation in worksite health promotion programmes. European Journal of Work and Organizational Psychology, 24(6), 866-881.

Trougakos, J., Hideg, I., Cheng, B., \& Beal, D. (2013). Lunch breaks unpacked: The role of autonomy as a moderator of recovery during lunch. Academy of Management Journal, 57(2), 405-421. 
Trougakos, J. P., \& Hideg, I. (2009). Momentary work-recovery: The role of within-day work breaks. In S. Sonnentag, P. L. Perrewé \& D. C. Ganster (Eds.), Current Perspectives on Job-Stress Recovery: Research in Occupational Stress and Well-being (Vol. 7, pp. 37-84). Bingley, United Kingdom: Emerald Group Publishing Limited.

Trougakos, J. P., Beal, D. J., Green, S. G., \& Weiss, H. M. (2008). Making the break count: An episodic examination of recovery activities, emotional experiences, and positive affective displays. Academy of Management Journal, 51(1), 131-146.

Tsunetsugu, Y., Lee, J., Park, B. J., Tyrväinen, L., Kagawa, T., \& Miyazaki, Y. (2013). Physiological and psychological effects of viewing urban forest landscapes assessed by multiple measurements. Landscape and Urban Planning, 113, 90-93.

Tuomisto, M. T. (2007). Syvähengitys ja kokemusten hyväksyminen - rentoutus- ja hyväksyntämenetelmä [Deep breathing and acceptance of experiences - a relaxation and acceptance method]. Käyttäytymisanalyysi ja-terapia, 12(3-4), 19-22.

Tyrväinen, L., Ojala, A., Korpela, K., Lanki, T., Tsunetsugu, Y., \& Kagawa, T. (2014). The influence of urban green environments on stress relief measures: A field experiment. Journal of Environmental Psychology, 38, 1-9.

Ulrich, R. S., Simons, R. F., Losito, B. D., Fiorito, E., Miles, M. A., \& Zelson, M. (1991). Stress recovery during exposure to natural and urban environments. Journal of Environmental Psychology, 11(3), 201-230.

Ursin, H., \& Eriksen, H. R. (2004). The cognitive activation theory of stress. Psychoneuroendocrinology, 29(5), 567-592.

Van Buuren, S., Groothuis-Oudshoorn, K. (2011). Mice: Multivariate imputation by chained equations. Journal of Statistical Software, 45(3), 1-67. 
Van der Linden, D., Frese, M., \& Meijman, T. F. (2003). Mental fatigue and the control of cognitive processes: Effects on perseveration and planning. Acta Psychologica, 113(1), 45-65.

van Dixhoorn, J., \& White, A. (2005). Relaxation therapy for rehabilitation and prevention in ischaemic heart disease: A systematic review and meta-analysis. European Journal of Cardiovascular Prevention \& Rehabilitation, 12(3), 193-202.

Van Hooff, M.L.M., Geurts, S.A.E., Taris, T.W., \& Kompier, M.A.J. (2007). "How fatigued do you currently feel?" Convergent and discriminant validity of a single-item fatigue measure. Journal of Occupational Health, 49, 224-234.

von Thiele Schwarz, U., \& Hasson, H. (2012). Effects of worksite health interventions involving reduced work hours and physical exercise on sickness absence costs. Journal of Occupational and Environmental Medicine, 54(5), 538-544.

Wanous, J. P., Reichers, A. E., \& Hudy, M. J. (1997). Overall job satisfaction: How good are singleitem measures? Journal of Applied Psychology, 82(2), 247-252.

Warr, P., Bindl, U. K., Parker, S. K., \& Inceoglu, I. (2014). Four-quadrant investigation of job-related affects and behaviours. European Journal of Work and Organizational Psychology, 23(3), 342-363.

Waterman, A. (2005). When effort is enjoyed: Two studies of intrinsic motivation for personally salient activities. Motivation and Emotion, 29(3), 165-188.

Wingerden, J. van, Bakker, A. B., \& Derks, D. (2016). A test of a job demands-resources intervention. Journal of Managerial Psychology, 31(3), 686-701.

Winwood, P.C., Bakker, A.B., \& Winefield, A.H. (2007). An investigation of the role of non-worktime behavior in buffering the effects of work strain. Journal of Occupational and Environmental Medicine, 49 (8), 862-871. 
Zacher, H., Brailsford, H. A., \& Parker, S. L. (2014). Micro-breaks matter: A diary study on the effects of energy management strategies on occupational well-being. Journal of Vocational Behavior, 85(3), 287-297. 
Tables and Figures

\begin{tabular}{|c|c|c|c|c|c|}
\hline Time of day & & $\begin{array}{c}\text { T1 } \\
\text { Baseline }\end{array}$ & \multicolumn{2}{|c|}{$\begin{array}{c}\mathrm{T2} \\
\text { Intervention }\end{array}$} & $\begin{array}{c}\text { T3 } \\
\text { Post Intervention }\end{array}$ \\
\hline 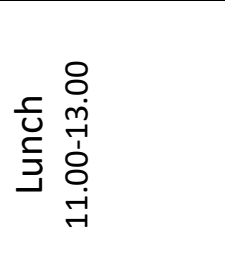 & & $\begin{array}{l}\text { - Restoration } \\
\text { - } \text { Fatigue }^{1}\end{array}$ & $\begin{array}{l}\text { 15-min intervention } \\
\text { walk/relax/control } \\
\text { - Manipul. check } \\
\text { - Restoration }{ }^{1} \\
\text { - } \text { Fatigue }^{1}\end{array}$ & $\begin{array}{l}\text { 15-min intervention } \\
\text { walk/relax/control } \\
\text { - Manipul. check } \\
\text { - Restoration }{ }^{1} \\
\text { - Fatigue }\end{array}$ & $\begin{array}{l}\text { - Restoration } \\
\text { - } \text { Fatigue }^{1}\end{array}$ \\
\hline 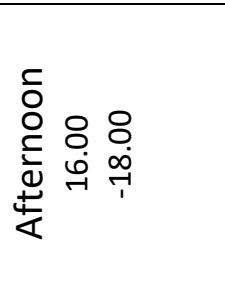 & $\begin{array}{l}\text { - Background \& job } \\
\text { information } \\
\text { - Baseline recovery }\end{array}$ & $\begin{array}{ll}\text { - } & \text { Fatigue }^{1} \\
\text { - } & \text { Relaxation }^{2} \\
\text { - } & \text { Detachment }^{2} \\
\text { - } & \text { Enjoyment }^{2} \\
\text { - } & \text { Job satisfaction }^{2}\end{array}$ & $\begin{array}{l}\text { - } \text { Fatigue }^{1} \\
\text { - } \text { Relaxation }^{2} \\
\text { - } \\
\text { - } \text { Detachment }^{2} \\
\text { - } \text { Enjoyment }^{2} \\
\text { Job satisfaction }^{2}\end{array}$ & $\begin{array}{l}\text { - } \text { Fatigue }^{1} \\
\text { - } \text { Relaxation }^{2} \\
\text { - } \\
\text { - } \text { Detachment }^{2} \\
\text { - } \text { Enjoyment }^{2} \\
\text { Job satisfaction }^{2}\end{array}$ & $\begin{array}{ll}\text { - } & \text { Fatigue }^{1} \\
\text { - } & \text { Relaxation }^{2} \\
\text { - } & \text { Detachment }^{2} \\
\text { - } & \text { Enjoyment }^{2} \\
\text { - } & \text { Job satisfaction }^{2}\end{array}$ \\
\hline 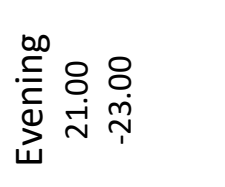 & & $\begin{array}{l}\text { - Restoration } \\
\text { - } \text { Fatigue }^{1}\end{array}$ & $\begin{array}{l}\text { - Restoration } \\
\text { - } \text { Fatigue }^{1}\end{array}$ & $\begin{array}{l}\text { - Restoration } \\
\text { - } \text { Fatigue }^{1}\end{array}$ & $\begin{array}{l}\text { - Restoration } \\
\text { - } \text { Fatigue }^{1}\end{array}$ \\
\hline$\stackrel{\frac{v}{\Perp}}{3}$ & $\begin{array}{l}\text { Week } 18 \\
\text { Week } 35\end{array}$ & $\begin{array}{l}\text { Week } 19 \\
\text { Week } 36 \\
\text { Tuesday \& Thursday }\end{array}$ & $\begin{array}{l}\text { Week } 20 \\
\text { Week } 37 \\
\text { Tuesday \& Thursday }\end{array}$ & $\begin{array}{l}\text { Week } 21 \\
\text { Week } 38 \\
\text { Tuesday \& Thursday }\end{array}$ & $\begin{array}{l}\text { Week } 22 \\
\text { Week } 39 \\
\text { Tuesday \& Thursday }\end{array}$ \\
\hline
\end{tabular}

\section{Figure 1}

Research design of the two RCTs

Note. ${ }^{0}=$ assessed via an online questionnaire. ${ }^{1}$ assessed via SMS. ${ }^{2}=$ assessed retrospectively via a paper-and-pencil questionnaire in the evening. 
Table I

Background characteristics for participants in the spring and fall RCTs

\begin{tabular}{|c|c|c|c|c|}
\hline \multicolumn{2}{|c|}{ Variable } & Spring & Fall & Difference $X^{2} / F$ \\
\hline \multicolumn{2}{|c|}{ Number of participants } & 83 & \multicolumn{2}{|l|}{70} \\
\hline \multirow{3}{*}{$\begin{array}{l}\text { 을 } \\
\text { ํํㄴ }\end{array}$} & Park walk & 28 & 23 & \multirow{3}{*}{$X^{2}(2,153)=0.53, p=.77$} \\
\hline & Relaxation & 23 & 23 & \\
\hline & Control & 32 & 24 & \\
\hline \multirow{6}{*}{\multicolumn{2}{|c|}{ Distribution companies (\%) }} & Public sector: 49 & Public sector: 46 & \multirow[t]{6}{*}{$X^{2}(6,153)=47.10, p<.01^{*}$} \\
\hline & & Administration: 13 & \multirow{5}{*}{$\begin{array}{l}\text { Education: } 49 \\
\text { Engineering: } 6\end{array}$} & \\
\hline & & Media: & & \\
\hline & & Health care: 16 & & \\
\hline & & Finance: & & \\
\hline & & Engineering: & & \\
\hline \multicolumn{2}{|c|}{$\%$ women } & 89.2 & 90.0 & $X^{2}(1,153)=0.03, p=.87$ \\
\hline \multicolumn{2}{|c|}{ Age in years } & 48.9 & 45.5 & $F(1,153)=5.64, p=.02 *$ \\
\hline \multirow{5}{*}{ 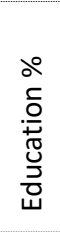 } & Vocational qualification & 8 & 7 & \multirow{5}{*}{$X^{2}(5,152)=5.71, p=.34$} \\
\hline & Specialist vocational qualification & 4 & 1 & \\
\hline & Vocational college qualification & 33 & 22 & \\
\hline & Bachelor`s degree & 23 & 19 & \\
\hline & Master`s degree or higher & 33 & 51 & \\
\hline \multirow{4}{*}{$\begin{array}{l}\text { 응 } \\
\frac{0}{d} \\
\stackrel{y}{y} \\
\text { 오 }\end{array}$} & Alone & 10 & 15 & \multirow{4}{*}{$X^{2}(3,144)=6.66, p=.08$} \\
\hline & Cohabiting without children & 39 & 26 & \\
\hline & Cohabiting with children & 44 & 58 & \\
\hline & Single parent & 8 & 2 & \\
\hline \multirow{4}{*}{ 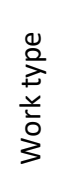 } & Manual/blue collar worker & 10 & 4 & \multirow{4}{*}{$X^{2}(3,152)=3.92, p=.27$} \\
\hline & Lower level white collar worker & 57 & 48 & \\
\hline & Upper level white collar worker & 30 & 44 & \\
\hline & Top management & 4 & 4 & \\
\hline \multicolumn{2}{|c|}{ Tenure in years } & 14.8 & 12.7 & $F(1,152)=1.50, p=.22$ \\
\hline \multicolumn{2}{|c|}{$\%$ permanent contract } & 92 & 88 & $X^{2}(1,152)=0.42, p=.52$ \\
\hline \multicolumn{2}{|c|}{$\%$ supervisory position } & 10 & 15 & $X^{2}(1,152)=0.85, p=.36$ \\
\hline We & ly work hours & 38.1 & 38.8 & $F(1,152)=1.26, p=.26$ \\
\hline$\%$ lu & ch break almost every day & 96 & 90 & $X^{2}(1,152)=2.54, p=.11$ \\
\hline $\begin{array}{l}\text { Len } \\
\text { bas }\end{array}$ & $\begin{array}{l}\text { h of usual lunch break in min at } \\
\text { ine }\end{array}$ & 28.0 & 27.1 & $F(1,153)=0.47, p=.50$ \\
\hline Rel & ation at baseline & 3.8 & 3.8 & $F(1,153)=0.00, p=.96$ \\
\hline Det & chment at baseline & 3.6 & 3.6 & $F(1,153)=0.08, p=.79$ \\
\hline Enj & ment of lunch break at baseline & 4.2 & 4.3 & $F(1,153)=0.12, p=.74$ \\
\hline Exh & ustion at baseline & 2.2 & 1.8 & $F(1,151)=5.62, p=.02 *$ \\
\hline Res & ration after lunch at baseline & 3.4 & 3.3 & $F(1,153)=0.51, p=.48$ \\
\hline Job & atisfaction (dedication) at baseline & 4.3 & 4.2 & $F(1,151)=0.44, p=.51$ \\
\hline $\begin{array}{l}\text { Inte } \\
\text { of } 1\end{array}$ & $\begin{array}{l}\text { Jention exercises completed (out } \\
\text { times) }\end{array}$ & 8.5 & 8.6 & $F(1,97)=0.04, p=.84$ \\
\hline Dur & ion intervention exercises in min & 15.0 & 14.3 & $F(1,90)=1.96, p=.17$ \\
\hline
\end{tabular}

* $p<.05$. 
Table II

Means and standard deviations of recovery experiences and well-being across time (T1 to T3) in spring and fall

\begin{tabular}{|c|c|c|c|c|c|c|c|c|c|c|c|c|c|c|c|c|c|c|c|}
\hline \multirow{4}{*}{$\begin{array}{l}\text { Time } \\
\text { of } \\
\text { day }\end{array}$} & \multirow{4}{*}{$\begin{array}{l}\text { Recovery experiences \& } \\
\text { well-being }\end{array}$} & \multicolumn{9}{|c|}{ Spring $(n=83)$} & \multicolumn{9}{|c|}{ Fall $(n=70)$} \\
\hline & & \multicolumn{2}{|c|}{$\begin{array}{l}\text { Park walk } \\
(n=28)\end{array}$} & \multicolumn{3}{|c|}{$\begin{array}{l}\text { Relaxation } \\
(n=23)\end{array}$} & \multirow{3}{*}{$\begin{array}{c}\text { T3 } \\
\text { M } \\
\text { (SD) }\end{array}$} & \multicolumn{2}{|c|}{$\begin{array}{l}\text { Control } \\
(n=32)\end{array}$} & \multirow{3}{*}{$\begin{array}{c}\text { T3 } \\
\text { M } \\
\text { (SD) }\end{array}$} & \multicolumn{2}{|c|}{$\begin{array}{l}\text { Park walk } \\
(n=23)\end{array}$} & \multirow{3}{*}{$\begin{array}{c}\text { T3 } \\
\text { M } \\
\text { (SD) }\end{array}$} & \multicolumn{2}{|c|}{$\begin{array}{l}\text { Relaxation } \\
(n=23)\end{array}$} & \multirow{3}{*}{$\begin{array}{c}\text { T3 } \\
\text { M } \\
\text { (SD) }\end{array}$} & \multicolumn{2}{|c|}{$\begin{array}{l}\text { Control } \\
(n=24)\end{array}$} & \multirow{3}{*}{$\begin{array}{c}\mathrm{T} 3 \\
\mathrm{M} \\
\text { (SD) }\end{array}$} \\
\hline & & $\mathrm{T} 1$ & $\mathrm{~T} 2$ & T3 & $\mathrm{T} 1$ & $\mathrm{~T} 2$ & & $\mathrm{~T} 1$ & $\mathrm{~T} 2$ & & $\mathrm{~T} 1$ & $\mathrm{~T} 2$ & & $\mathrm{~T} 1$ & $\mathrm{~T} 2$ & & $\mathrm{~T} 1$ & $\mathrm{~T} 2$ & \\
\hline & & $\begin{array}{c}M \\
(S D)\end{array}$ & $\begin{array}{c}M \\
(S D)\end{array}$ & $\begin{array}{c}M \\
(S D)\end{array}$ & $\begin{array}{c}M \\
(S D)\end{array}$ & $\begin{array}{c}\mathrm{M} \\
(\mathrm{SD})\end{array}$ & & $\begin{array}{c}\mathrm{M} \\
(\mathrm{SD})\end{array}$ & $\begin{array}{c}M \\
(S D)\end{array}$ & & $\begin{array}{c}M \\
(S D)\end{array}$ & $\begin{array}{c}M \\
(S D)\end{array}$ & & $\begin{array}{c}M \\
(S D)\end{array}$ & $\begin{array}{c}M \\
(S D)\end{array}$ & & $\begin{array}{c}M \\
(S D)\end{array}$ & $\begin{array}{c}M \\
(S D)\end{array}$ & \\
\hline \multirow{5}{*}{ 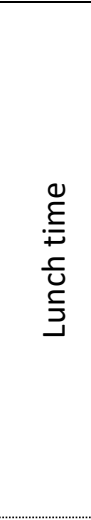 } & & $\begin{array}{l}3.79 \\
(0.9)\end{array}$ & $\begin{array}{l}3.90 \\
(0.8)\end{array}$ & $\begin{array}{l}3.65 \\
(0.9)\end{array}$ & $\begin{array}{l}3.65 \\
(1.2)\end{array}$ & $\begin{array}{l}3.77 \\
(0.8)\end{array}$ & $\begin{array}{l}3.70 \\
(1.0)\end{array}$ & $\begin{array}{l}3.78 \\
(0.8)\end{array}$ & $\begin{array}{l}3.87 \\
(0.7)\end{array}$ & $\begin{array}{l}3.83 \\
(0.7)\end{array}$ & $\begin{array}{l}3.57 \\
(1.0)\end{array}$ & $\begin{array}{l}4.13 \\
(0.5)\end{array}$ & $\begin{array}{l}3.59 \\
(0.9)\end{array}$ & $\begin{array}{l}3.48 \\
(1.0)\end{array}$ & $\begin{array}{l}3.89 \\
(0.7)\end{array}$ & $\begin{array}{l}3.61 \\
(1.0)\end{array}$ & $\begin{array}{l}3.71 \\
(0.9)\end{array}$ & $\begin{array}{l}3.66 \\
(0.7)\end{array}$ & $\begin{array}{l}3.59 \\
(0.9)\end{array}$ \\
\hline & Deta & $\begin{array}{l}3.11 \\
(1.1)\end{array}$ & $\begin{array}{l}3.09 \\
(1.1)\end{array}$ & $\begin{array}{l}2.98 \\
(1.2)\end{array}$ & $\begin{array}{l}3.09 \\
(1.1)\end{array}$ & $\begin{array}{l}3.19 \\
(0.9)\end{array}$ & $\begin{array}{l}3.36 \\
(1.0)\end{array}$ & $\begin{array}{l}2.92 \\
(0.9)\end{array}$ & $\begin{array}{l}3.04 \\
(1.0)\end{array}$ & $\begin{array}{l}2.90 \\
(1.1)\end{array}$ & $\begin{array}{l}2.83 \\
(1.1)\end{array}$ & $\begin{array}{l}3.37 \\
(0.8)\end{array}$ & $\begin{array}{l}2.70 \\
(1.0)\end{array}$ & $\begin{array}{l}2.83 \\
(1.2)\end{array}$ & $\begin{array}{l}2.88 \\
(0.9)\end{array}$ & $\begin{array}{l}2.36 \\
(1.1)\end{array}$ & $\begin{array}{l}2.88 \\
(1.1)\end{array}$ & $\begin{array}{l}2.82 \\
(1.0)\end{array}$ & $\begin{array}{l}2.82 \\
(1.2)\end{array}$ \\
\hline & Enjoyment lunch break (PP) & $\begin{array}{l}4.00 \\
(0.8)\end{array}$ & $\begin{array}{l}4.03 \\
(0.8)\end{array}$ & $\begin{array}{l}3.69 \\
(0.9)\end{array}$ & $\begin{array}{l}3.98 \\
(0.8)\end{array}$ & $\begin{array}{l}3.97 \\
(0.7)\end{array}$ & $\begin{array}{l}3.80 \\
(1.1)\end{array}$ & $\begin{array}{l}3.81 \\
(0.7)\end{array}$ & $\begin{array}{l}3.89 \\
(0.6)\end{array}$ & $\begin{array}{l}3.79 \\
(0.9)\end{array}$ & $\begin{array}{l}3.50 \\
(1.0)\end{array}$ & $\begin{array}{l}4.02 \\
(0.6)\end{array}$ & $\begin{array}{l}3.34 \\
(1.0)\end{array}$ & $\begin{array}{l}3.74 \\
(0.7)\end{array}$ & $\begin{array}{l}3.67 \\
(0.7)\end{array}$ & $\begin{array}{l}3.57 \\
(1.0)\end{array}$ & $\begin{array}{l}3.81 \\
(0.7)\end{array}$ & $\begin{array}{l}3.60 \\
(0.9)\end{array}$ & $\begin{array}{l}3.59 \\
(0.9)\end{array}$ \\
\hline & Resto & $\begin{array}{l}4.38 \\
(1.5)\end{array}$ & $\begin{array}{l}4.74 \\
(1.3)\end{array}$ & $\begin{array}{l}4.67 \\
(1.3)\end{array}$ & $\begin{array}{l}4.76 \\
(1.2)\end{array}$ & $\begin{array}{l}5.05 \\
(0.9)\end{array}$ & $\begin{array}{l}4.50 \\
(1.4)\end{array}$ & $\begin{array}{l}4.22 \\
(1.5)\end{array}$ & $\begin{array}{l}4.78 \\
(1.1)\end{array}$ & $\begin{array}{l}4.46 \\
(1.1)\end{array}$ & $\begin{array}{l}4.50 \\
(1.0)\end{array}$ & $\begin{array}{l}4.93 \\
(0.8)\end{array}$ & $\begin{array}{l}4.36 \\
(1.0)\end{array}$ & $\begin{array}{l}4.20 \\
(1.0)\end{array}$ & $\begin{array}{l}4.85 \\
(0.8)\end{array}$ & $\begin{array}{l}4.52 \\
(1.2)\end{array}$ & $\begin{array}{l}4.93 \\
(0.9)\end{array}$ & $\begin{array}{l}4.90 \\
(1.0)\end{array}$ & $\begin{array}{l}5.07 \\
(1.2)\end{array}$ \\
\hline & Fati६ & $\begin{array}{l}3.48 \\
(1.8)\end{array}$ & $\begin{array}{l}3.13 \\
(1.3)\end{array}$ & $\begin{array}{l}3.50 \\
(1.7)\end{array}$ & $\begin{array}{l}3.16 \\
(1.5)\end{array}$ & $\begin{array}{l}3.00 \\
(1.1)\end{array}$ & $\begin{array}{l}3.28 \\
(1.5)\end{array}$ & $\begin{array}{l}3.21 \\
(1.5)\end{array}$ & $\begin{array}{l}2.79 \\
(1.1)\end{array}$ & $\begin{array}{l}3.15 \\
(1.5)\end{array}$ & $\begin{array}{l}3.35 \\
(1.5)\end{array}$ & $\begin{array}{l}2.82 \\
(1.0)\end{array}$ & $\begin{array}{l}3.10 \\
(1.5)\end{array}$ & $\begin{array}{l}3.39 \\
(1.3)\end{array}$ & $\begin{array}{l}3.03 \\
(0.8)\end{array}$ & $\begin{array}{l}3.40 \\
(1.6)\end{array}$ & $\begin{array}{l}3.09 \\
(1.4)\end{array}$ & $\begin{array}{l}3.41 \\
(1.1)\end{array}$ & $\begin{array}{l}2.95 \\
(1.3)\end{array}$ \\
\hline \multirow{2}{*}{ 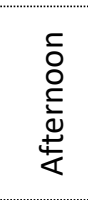 } & $\mathrm{JC}$ & $\begin{array}{l}3.48 \\
(0.9)\end{array}$ & $\begin{array}{l}3.50 \\
(0.8)\end{array}$ & $\begin{array}{l}3.42 \\
(0.8)\end{array}$ & $\begin{array}{l}3.30 \\
(1.0)\end{array}$ & $\begin{array}{l}3.68 \\
(0.6)\end{array}$ & $\begin{array}{l}3.41 \\
(1.0)\end{array}$ & $\begin{array}{l}3.61 \\
(0.6)\end{array}$ & $\begin{array}{l}3.62 \\
(0.6)\end{array}$ & $\begin{array}{l}3.71 \\
(0.7)\end{array}$ & $\begin{array}{l}3.41 \\
(0.9)\end{array}$ & $\begin{array}{l}3.57 \\
(0.6)\end{array}$ & $\begin{array}{l}3.48 \\
(0.8)\end{array}$ & $\begin{array}{l}3.48 \\
(0.7)\end{array}$ & $\begin{array}{l}3.84 \\
(0.5)\end{array}$ & $\begin{array}{l}3.66 \\
(0.8)\end{array}$ & $\begin{array}{l}3.60 \\
(0.7)\end{array}$ & $\begin{array}{l}3.70 \\
(0.6)\end{array}$ & $\begin{array}{l}3.61 \\
(0.6)\end{array}$ \\
\hline & Fatigue (SMS) & $\begin{array}{l}3.83 \\
(1.7)\end{array}$ & $\begin{array}{l}4.11 \\
(1.6)\end{array}$ & $\begin{array}{l}4.15 \\
(1.8)\end{array}$ & $\begin{array}{l}4.12 \\
(1.5)\end{array}$ & $\begin{array}{l}3.57 \\
(1.3)\end{array}$ & $\begin{array}{l}3.89 \\
(1.4)\end{array}$ & $\begin{array}{l}3.95 \\
(1.4)\end{array}$ & $\begin{array}{l}3.49 \\
(1.1)\end{array}$ & $\begin{array}{l}4.00 \\
(1.6)\end{array}$ & $\begin{array}{l}4.04 \\
(1.5)\end{array}$ & $\begin{array}{l}3.33 \\
(1.2)\end{array}$ & $\begin{array}{l}3.55 \\
(1.7)\end{array}$ & $\begin{array}{l}3.78 \\
(1.4)\end{array}$ & $\begin{array}{l}3.29 \\
(1.0)\end{array}$ & $\begin{array}{l}4.26 \\
(1.3)\end{array}$ & $\begin{array}{l}3.80 \\
(1.5)\end{array}$ & $\begin{array}{l}3.94 \\
(1.4)\end{array}$ & $\begin{array}{l}4.34 \\
(1.8)\end{array}$ \\
\hline \multirow{2}{*}{ 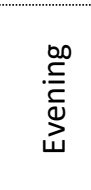 } & MS) & $\begin{array}{l}4.74 \\
(1.6)\end{array}$ & $\begin{array}{l}4.79 \\
(1.3)\end{array}$ & $\begin{array}{l}4.87 \\
(1.4)\end{array}$ & $\begin{array}{l}5.02 \\
(1.4)\end{array}$ & $\begin{array}{l}4.29 \\
(1.7)\end{array}$ & $\begin{array}{l}4.69 \\
(1.4)\end{array}$ & $\begin{array}{l}4.63 \\
(1.4)\end{array}$ & $\begin{array}{l}4.51 \\
(1.5)\end{array}$ & $\begin{array}{l}4.79 \\
(1.0)\end{array}$ & $\begin{array}{l}4.78 \\
(1.2)\end{array}$ & $\begin{array}{l}5.11 \\
(0.9)\end{array}$ & $\begin{array}{l}4.93 \\
(1.3)\end{array}$ & $\begin{array}{l}5.15 \\
(1.3)\end{array}$ & $\begin{array}{l}5.03 \\
(1.1)\end{array}$ & $\begin{array}{l}4.71 \\
(1.3)\end{array}$ & $\begin{array}{l}4.66 \\
(1.1)\end{array}$ & $\begin{array}{l}4.86 \\
(1.3)\end{array}$ & $\begin{array}{l}4.72 \\
(1.5)\end{array}$ \\
\hline & Fatigue (SMS) & $\begin{array}{l}4.93 \\
(1.7)\end{array}$ & $\begin{array}{l}4.75 \\
(1.6)\end{array}$ & $\begin{array}{l}4.59 \\
(1.8)\end{array}$ & $\begin{array}{l}4.61 \\
(1.6)\end{array}$ & $\begin{array}{l}4.60 \\
(1.6)\end{array}$ & $\begin{array}{l}4.28 \\
(1.8)\end{array}$ & $\begin{array}{l}4.67 \\
(1.5)\end{array}$ & $\begin{array}{l}4.51 \\
(1.4)\end{array}$ & $\begin{array}{l}5.09 \\
(1.5)\end{array}$ & $\begin{array}{l}5.41 \\
(1.2)\end{array}$ & $\begin{array}{l}5.29 \\
(0.9)\end{array}$ & $\begin{array}{l}5.18 \\
(1.2)\end{array}$ & $\begin{array}{l}5.07 \\
(1.3)\end{array}$ & $\begin{array}{l}4.95 \\
(1.0)\end{array}$ & $\begin{array}{l}5.11 \\
(1.4)\end{array}$ & $\begin{array}{l}5.02 \\
(1.3)\end{array}$ & $\begin{array}{l}5.24 \\
(1.3)\end{array}$ & $\begin{array}{l}5.11 \\
(1.7)\end{array}$ \\
\hline
\end{tabular}

Note. Based on non-imputed data set. T1 $=$ before intervention (average of $1^{\text {st }}$ and $2^{\text {nd }}$ measurement occasion). T2 $=$ during intervention (average of $3^{\text {rd }}, 4^{\text {th }}, 5^{\text {th }}$ and $6^{\text {th }}$ measurement occasion). T3 $=$ after intervention (average of $7^{\text {th }}$ and $8^{\text {th }}$ measurement occasion). PP $=$ assessed retrospectively with a paper-and-pencil questionnaire in the evening after work on a scale from 1 to 5 . SMS = assessed with SMS questionnaire on a scale from 1 to 7. 
Table III

Results of repeated measures ANOVA's for effects between groups (park walk, relaxation and control group), across time (T1, T2 \& T3) and for group $x$ time interactions for spring and fall RCT

\begin{tabular}{|c|c|c|c|c|c|c|c|}
\hline \multirow[b]{2}{*}{$\begin{array}{l}\text { Time } \\
\text { of } \\
\text { day }\end{array}$} & \multirow[b]{2}{*}{$\begin{array}{l}\text { Recovery experiences \& } \\
\text { well-being }\end{array}$} & \multicolumn{3}{|l|}{ Spring } & \multicolumn{3}{|l|}{ Fall } \\
\hline & & $\begin{array}{l}\text { F-value } \\
\text { Group } \\
\text { effect }\end{array}$ & $\begin{array}{l}\text { Time } \\
\text { effect }\end{array}$ & $\begin{array}{l}\text { Group x Time } \\
\text { effect }\end{array}$ & $\begin{array}{l}\text { F-value } \\
\text { Group } \\
\text { effect }\end{array}$ & $\begin{array}{l}\text { Time } \\
\text { effect }\end{array}$ & Group x Time effect \\
\hline \multirow{4}{*}{ 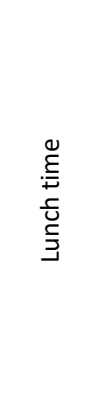 } & Relaxation (PP) & 0.05 & 1.44 & 0.46 & 0.07 & $7.69 *$ & $2.01^{\wedge}$ \\
\hline & Detachment (PP) & 0.89 & 0.27 & 0.37 & 0.51 & $4.78^{*}$ & $2.52 *$ \\
\hline & Restoration (SMS) & 0.39 & $10.50^{*}$ & 0.74 & 1.65 & $2.96^{\wedge}$ & 1.83 \\
\hline & Fatigue (SMS) & 0.61 & $3.91 *$ & 1.24 & 0.04 & 1.22 & 1.29 \\
\hline 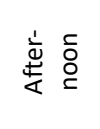 & Job satisfaction (PP) & 0.70 & 1.61 & 1.81 & 0.60 & $2.91^{\wedge}$ & 0.39 \\
\hline : & Fatigue (SMS) & 0.69 & 0.32 & 0.89 & 0.25 & 0.47 & 0.49 \\
\hline
\end{tabular}

Note. Based on non-imputed data set. T1 = before intervention (average of $1^{\text {st }}$ and $2^{\text {nd }}$ measurement occasion). T2 $=$ during intervention (average of $3^{\text {rd }}, 4^{\text {th }}, 5^{\text {th }}$ and $6^{\text {th }}$ measurement occasion). T3 = after intervention (average of $7^{\text {th }}$ and $8^{\text {th }}$

measurement occasion). ${ }^{*} p<.05 .{ }^{\wedge} p<.10$ (marginally significant). $\mathrm{PP}=$ assessed retrospectively with a paper-and-pencil questionnaire in the evening after work. SMS = assessed with SMS questionnaire. 
Effect size Cohen $d$ for changes in recovery experiences and well-being during and after intervention period within groups for spring and fall RCT

\begin{tabular}{|c|c|c|c|c|c|c|c|c|c|c|c|c|c|}
\hline \multirow{3}{*}{$\begin{array}{l}\text { Time } \\
\text { of day }\end{array}$} & \multirow{3}{*}{$\begin{array}{l}\text { Recovery experiences \& well- } \\
\text { being }\end{array}$} & \multicolumn{6}{|l|}{ Spring } & \multicolumn{6}{|l|}{ Fall } \\
\hline & & \multicolumn{3}{|c|}{$\begin{array}{l}\text { Intervention effect } \\
\text { (T1 vs. T2) }\end{array}$} & \multicolumn{3}{|c|}{$\begin{array}{l}\text { Post-intervention effect } \\
\text { (T1 vs. T3) }\end{array}$} & \multicolumn{3}{|c|}{$\begin{array}{l}\text { Intervention effect } \\
\text { (T1 vs. T2) }\end{array}$} & \multicolumn{3}{|c|}{$\begin{array}{l}\text { Post-intervention effect } \\
\text { (T1 vs. T3) }\end{array}$} \\
\hline & & $\begin{array}{l}\text { Park } \\
\text { walk }\end{array}$ & Relax & Control & $\begin{array}{l}\text { Park } \\
\text { walk }\end{array}$ & Relax & Control & $\begin{array}{l}\text { Park } \\
\text { walk }\end{array}$ & Relax & Control & $\begin{array}{l}\text { Park } \\
\text { walk }\end{array}$ & Relax & Control \\
\hline \multirow{7}{*}{ 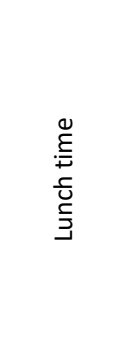 } & Relaxation (PP) & 0.12 & 0.15 & 0.11 & -0.18 & 0.06 & -0.06 & $0.66^{*}$ & $0.61^{*}$ & -0.05 & 0.02 & 0.13 & -0.14 \\
\hline & Detachment (PP) & -0.01 & 0.14 & 0.14 & -0.13 & 0.20 & -0.03 & $0.61^{*}$ & 0.06 & -0.05 & 0.09 & -0.52 & -0.05 \\
\hline & Enjoyment lunch break (PP) & 0.05 & -0.01 & 0.10 & -0.38 & -0.17 & -0.03 & $0.47^{*}$ & -0.09 & -0.26 & -0.12 & -0.21 & -0.24 \\
\hline & Average & 0.05 & 0.09 & 0.12 & -0.23 & 0.03 & -0.04 & 0.58 & 0.19 & -0.12 & 0.00 & -0.20 & -0.14 \\
\hline & Restoration (SMS) & 0.17 & 0.27 & 0.47 & 0.23 & -0.13 & 0.15 & 0.33 & $0.58 *$ & -0.04 & -0.12 & 0.20 & 0.13 \\
\hline & Fatigue (SMS) & 0.23 & 0.15 & 0.37 & 0.01 & -0.13 & 0.03 & 0.52 & $0.30 *$ & -0.22 & 0.17 & 0.01 & 0.09 \\
\hline & Average & 0.20 & 0.21 & 0.42 & 0.12 & -0.13 & 0.09 & 0.43 & 0.44 & -0.13 & 0.03 & 0.11 & 0.11 \\
\hline \multirow{3}{*}{ 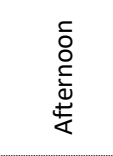 } & Job satisfaction (PP) & 0.02 & $0.65^{*}$ & 0.01 & -0.07 & 0.11 & 0.14 & 0.22 & $0.52^{*}$ & 0.13 & 0.08 & 0.19 & 0.01 \\
\hline & Fatigue (SMS) & $-0.19 *$ & 0.37 & 0.27 & -0.22 & 0.14 & -0.02 & $0.54^{*}$ & 0.37 & -0.10 & $0.29 *$ & -0.31 & -0.30 \\
\hline & Average & -0.09 & 0.51 & 0.14 & -0.15 & 0.13 & 0.06 & 0.38 & 0.45 & 0.02 & 0.19 & -0.06 & -0.15 \\
\hline \multirow{3}{*}{ 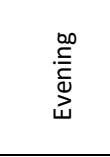 } & Restoration (SMS) & -0.03 & $-0.54 *$ & 0.07 & 0.12 & $-0.18 *$ & 0.14 & 0.26 & -0.10 & 0.17 & 0.13 & $-0.27 *$ & 0.04 \\
\hline & Fatigue (SMS) & 0.12 & 0.01 & -0.10 & 0.19 & 0.25 & -0.21 & 0.11 & 0.08 & -0.25 & 0.24 & -0.03 & -0.06 \\
\hline & Average & 0.05 & -0.27 & -0.02 & 0.16 & 0.04 & -0.04 & 0.19 & -0.01 & -0.04 & 0.19 & -0.15 & -0.01 \\
\hline \multicolumn{2}{|c|}{ Average effect size } & 0.05 & 0.14 & 0.17 & -0.02 & 0.02 & 0.02 & 0.39 & 0.27 & -0.07 & 0.10 & -0.08 & -0.05 \\
\hline \multicolumn{14}{|c|}{$\begin{array}{l}\text { Note. Based on non-imputed data set. T1 = before intervention (average of } 1^{\text {st }} \text { and } 2^{\text {nd }} \text { measurement occasion). T2 }=\text { during intervention (average of } 3^{\text {rd }}, 4^{\text {th }}, 5^{\text {th }} \\
\text { and } 6^{\text {th }} \text { measurement occasion). T3 = after intervention (average of } 7^{\text {th }} \text { and } 8^{\text {th }} \text { measurement occasion). }-=\text { deterioration in recovery experiences and well-being } \\
\text { (e.g., higher levels of fatigue, lower levels of restoration). No sign }=\text { improvement in recovery experiences and well-being (e.g., lower levels of fatigue, higher } \\
\text { levels of restoration). . }\end{array}$} \\
\hline
\end{tabular}


Appendix 1

Means of recovery experiences and well-being before $(\mathrm{T} 1, \mathrm{~T} 2)$, during (T3-T6) and after the intervention period $(T 7, T 8)$ in the spring RCT $(\mathrm{N}=83)$

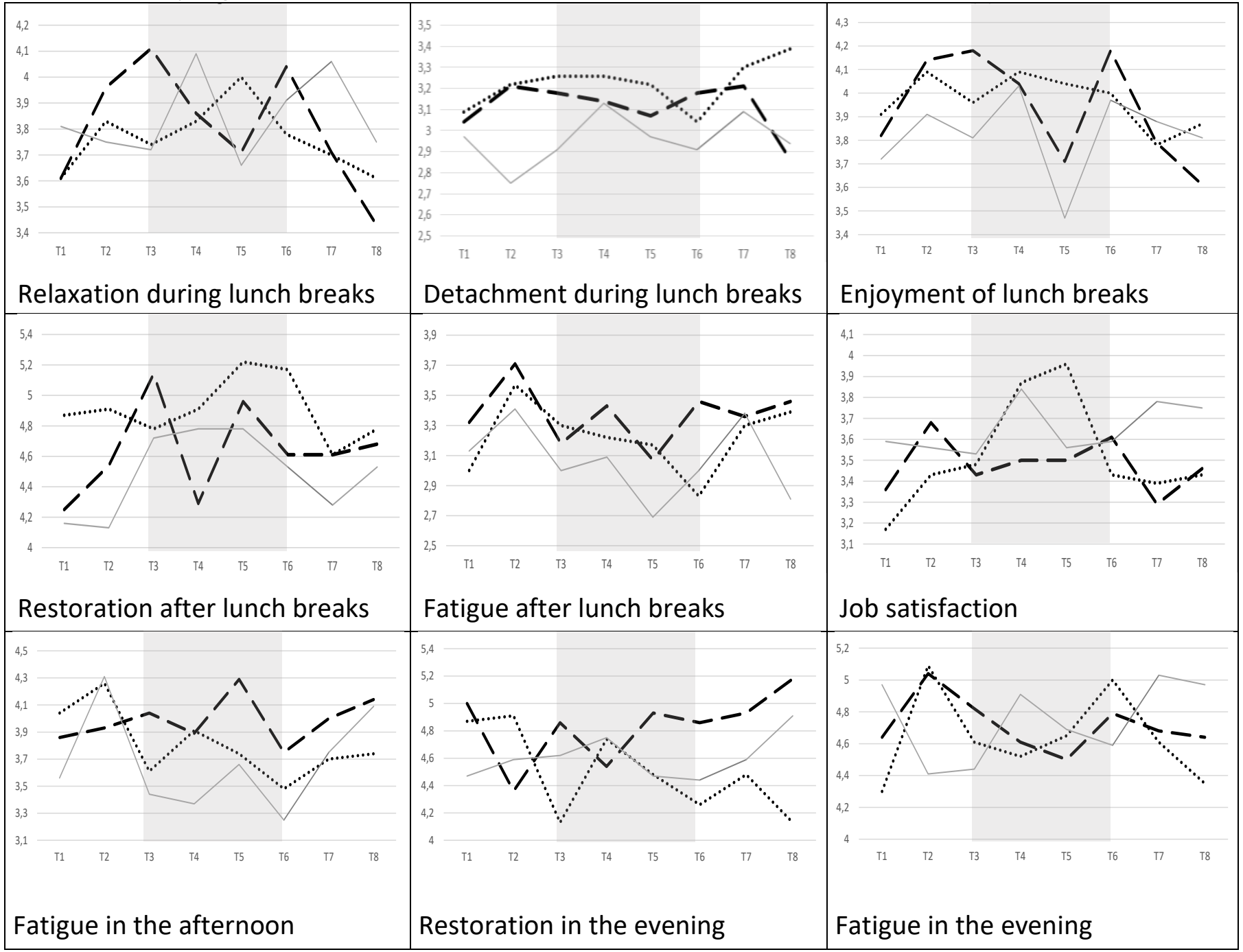

Note: $\longrightarrow$ Walking $\bullet \bullet \cdot \bullet \cdot$ Relaxation Control

Based on imputed data set. $\mathrm{T} 1 \&$ T2 = Baseline. T3, T4, T5, T6 = Intervention period. $\mathrm{T} 6 \& \mathrm{~T} 7=$ Post intervention. For clarity and detail, the scale of the graphs was adapted to the lowest/highest averages for each variable. The original scales ranged from 1-5 for relaxation, detachment, enjoyment and job satisfaction, and from 1-7 for restoration and fatigue. 
Appendix 2

Means of recovery experiences and outcomes before $(\mathrm{T} 1, \mathrm{~T} 2)$, during $(\mathrm{T} 3-\mathrm{T} 6)$ and after the intervention period $(\mathrm{T7}, \mathrm{T} 8)$ in the fall RCT $(\mathrm{N}=70)$

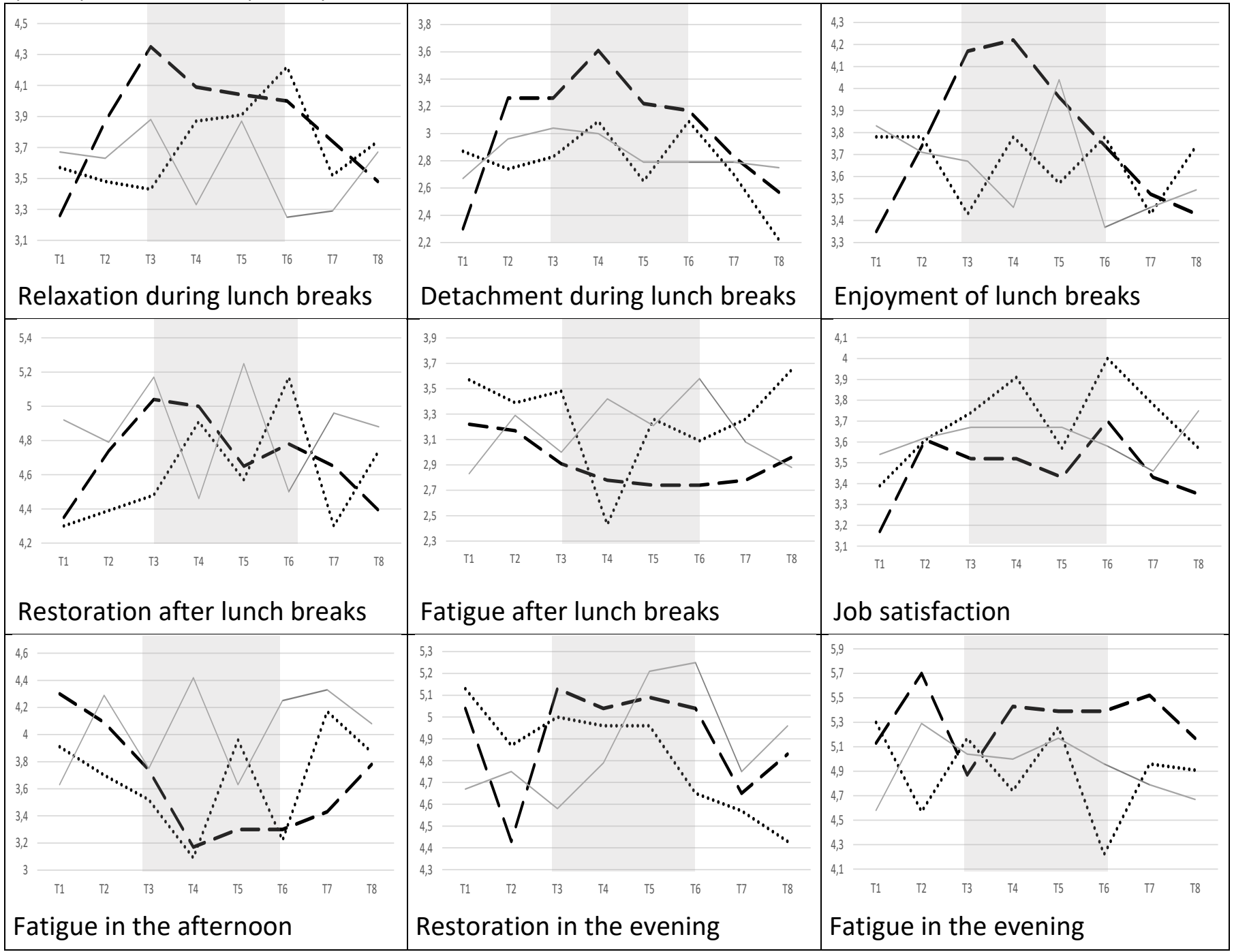

Note: $\longrightarrow$ Walking $\bullet \bullet \bullet \cdot$ Relaxation Control

Based on imputed data set. $\mathrm{T} 1 \&$ T2 = Baseline. $\mathrm{T} 3, \mathrm{~T} 4, \mathrm{~T} 5, \mathrm{~T} 6=$ Intervention period. $\mathrm{T} 6 \& \mathrm{~T} 7=$ Post intervention. For clarity and detail, the scale of the graphs was adapted to the lowest/highest averages for each variable. The original scales ranged from 1-5 for relaxation, detachment, enjoyment and job satisfaction, and from 1-7 for restoration and fatigue. 
Appendix 3

Hypotheses testing based on effect sizes reported in Table IV

\begin{tabular}{|c|c|c|c|c|}
\hline Nr. & Hypotheses & $\begin{array}{c}\text { Recovery experience } \& \\
\text { well-being }\end{array}$ & Spring & Fall \\
\hline \multirow{3}{*}{$\mathrm{H} 1.1$} & \multirow{3}{*}{$\begin{array}{l}\text { Employees engaging in a) park walking or b) } \\
\text { relaxation during lunch breaks will report more } \\
\text { beneficial recovery experiences during the } \\
\text { intervention period than before. }\end{array}$} & Relaxation & - & Walk \& Relax \\
\hline & & Detachment & - & Walk \\
\hline & & Enjoyment & - & Walk \\
\hline \multirow{3}{*}{$\mathrm{H} 1.2$} & \multirow{3}{*}{$\begin{array}{l}\text { Employees engaging in a) park walking or b) } \\
\text { relaxation during lunch breaks will experience } \\
\text { more beneficial recovery experiences during the } \\
\text { intervention period than employees continuing } \\
\text { their normal break routines. }\end{array}$} & Relaxation & - & Walk \& Relax \\
\hline & & Detachment & - & Walk \\
\hline & & Enjoyment & - & Walk \\
\hline \multirow{6}{*}{$\mathrm{H} 2.1$} & \multirow{6}{*}{$\begin{array}{l}\text { Employees engaging in a) park walking or b) } \\
\text { relaxation during lunch breaks will report higher } \\
\text { levels of well-being during the intervention } \\
\text { period than before. }\end{array}$} & Restoration lunch time & Relax & Walk \& Relax \\
\hline & & Fatigue lunch time & Walk & Walk \& Relax \\
\hline & & Job satisfaction & Relax & Walk \& Relax \\
\hline & & Fatigue afternoon & Relax & Walk \& Relax \\
\hline & & Restoration evening & lower restoration in Relax & Walk \\
\hline & & Fatigue evening & - & - \\
\hline \multirow{6}{*}{$\mathrm{H} 2.2$} & \multirow{6}{*}{$\begin{array}{l}\text { Employees engaging in a) park walking or b) } \\
\text { relaxation during lunch breaks will report higher } \\
\text { levels of well-being during the intervention } \\
\text { period than employees continuing their normal } \\
\text { break routines. }\end{array}$} & Restoration lunch time & - & - \\
\hline & & Fatigue lunch time & - & - \\
\hline & & Job satisfaction & Relax & - \\
\hline & & Fatigue afternoon & - & Walk \\
\hline & & Restoration evening & - & - \\
\hline & & Fatigue evening & - & - \\
\hline \multirow{5}{*}{ H3 } & \multirow{5}{*}{$\begin{array}{l}\text { Employees engaging in a) park walking or b) } \\
\text { relaxation during lunch breaks will experience } \\
\text { higher levels of well-being after the intervention } \\
\text { than before. }\end{array}$} & Restoration lunch time & Walk & Relax \\
\hline & & Job satisfaction & - & - \\
\hline & & Fatigue afternoon & - & Walk \& higher fatigue in Relax \\
\hline & & Restoration evening & lower in Relax & lower restoration in Relax \\
\hline & & Fatigue evening & Relax & Walk \\
\hline $\mathrm{H} 4$ & $\begin{array}{l}\text { On a daily level, we anticipate that the effects } \\
\text { on well-being will be stronger after the lunch } \\
\text { break than in the afternoon and in the evening. }\end{array}$ & & Not supported & $\begin{array}{l}\text { - Supported for Walk } \\
\text { - For Relax, most effects in } \\
\text { well-being (and not recovery } \\
\text { experiences). Similar effects } \\
\text { after lunch and in the } \\
\text { afternoon. }\end{array}$ \\
\hline
\end{tabular}

Note: Effect sizes $>0.2$ are considered meaningful. Walk = Results supported for walking group. Relax $=$ Results supported for relaxation group. Based on original, non-imputed data set and 3 averaged measurements (pre, during, post intervention). 